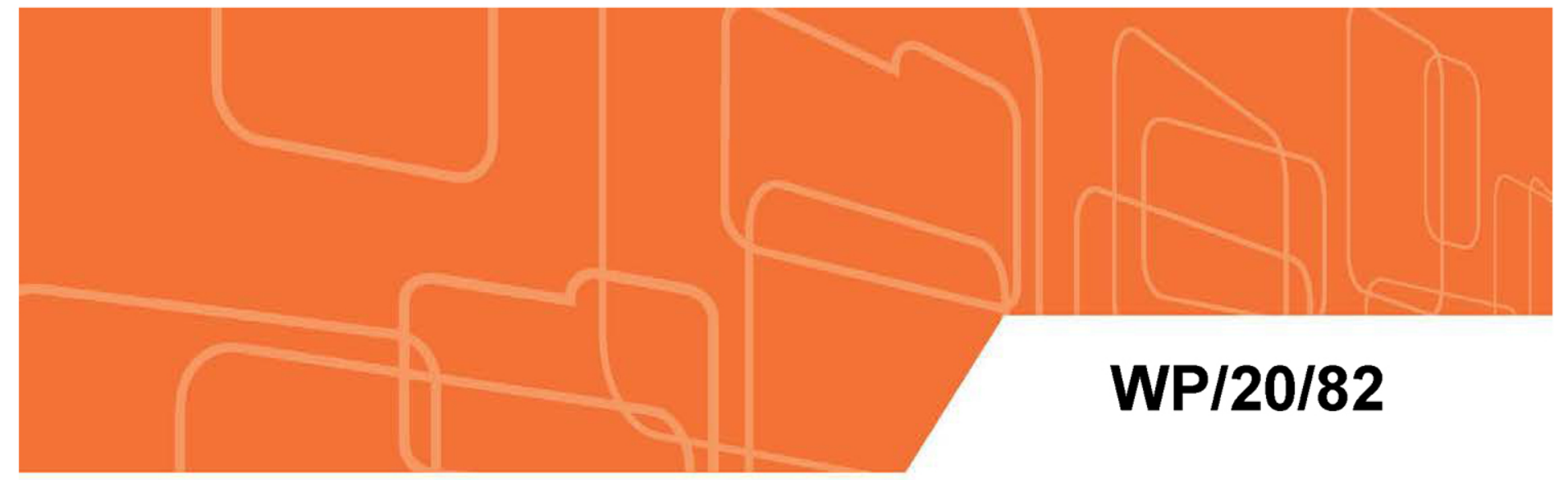

\title{
Liquidity at Risk: Joint Stress Testing of Solvency and Liquidity
}

by Rama Cont, Artur Kotlicki, and Laura Valderrama

IMF Working Papers describe research in progress by the author(s) and are published to elicit comments and to encourage debate. The views expressed in IMF Working Papers are those of the author(s) and do not necessarily represent the views of the IMF, its Executive Board, or IMF management. 


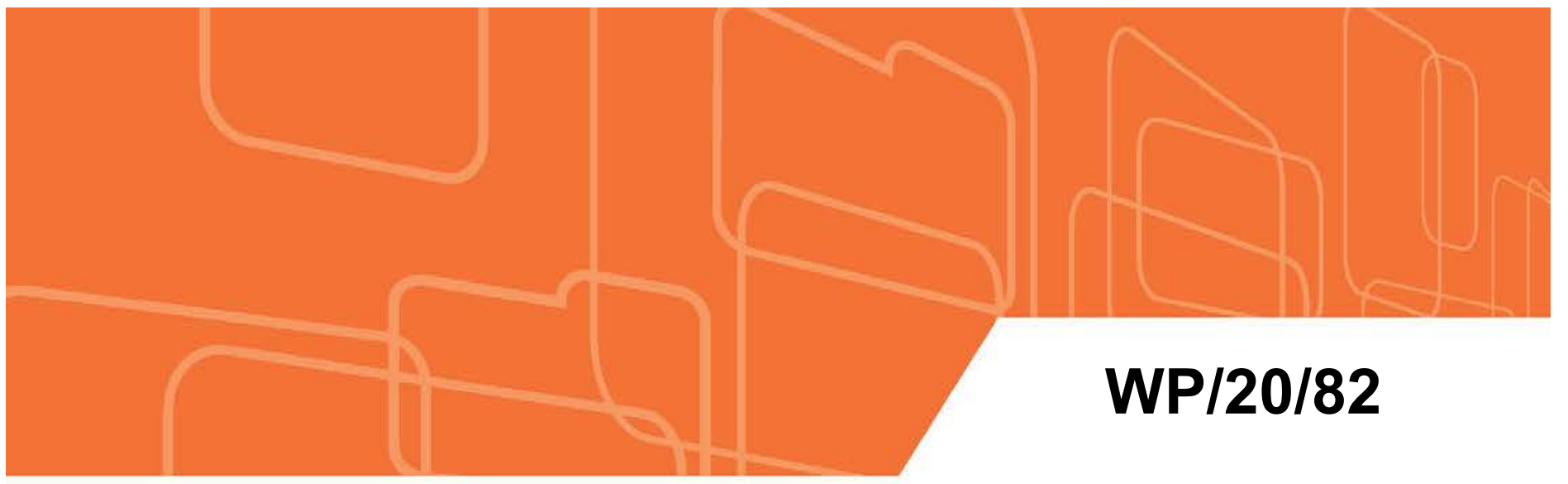

\section{IMF Working Paper}

\section{Liquidity at Risk: Joint Stress Testing of Solvency and Liquidity}

by Rama Cont, Artur Kotlicki, and Laura Valderrama

IMF Working Papers describe research in progress by the author(s) and are published to elicit comments and to encourage debate. The views expressed in IMF Working Papers are those of the author(s) and do not necessarily represent the views of the IMF, its Executive Board, or IMF management.

$$
\text { I N T E R N A T I O N A L M O NET A R Y F U N D }
$$




\title{
IMF Working Paper
}

Monetary and Capital Markets Department

\section{Liquidity at Risk: Joint Stress Testing of Solvency and Liquidity*}

\author{
Prepared by Rama Cont, Artur Kotlicki, and Laura Valderrama
}

Authorized for distribution by Martin Čihák

June 2020

\begin{abstract}
IMF Working Papers describe research in progress by the author(s) and are published to elicit comments and to encourage debate. The views expressed in IMF Working Papers are those of the author(s) and do not necessarily represent the views of the IMF, its Executive Board, or IMF management.
\end{abstract}

\begin{abstract}
The traditional approach to the stress testing of financial institutions focuses on capital adequacy and solvency. Liquidity stress tests have been applied in parallel to and independently from solvency stress tests, based on scenarios which may not be consistent with those used in solvency stress tests. We propose a structural framework for the joint stress testing of solvency and liquidity: our approach exploits the mechanisms underlying the solvency-liquidity nexus to derive relations between solvency shocks and liquidity shocks. These relations are then used to model liquidity and solvency risk in a coherent framework, involving external shocks to solvency and endogenous liquidity shocks arising from these solvency shocks. We define the concept of 'Liquidity at Risk', which quantifies the liquidity resources required for a financial institution facing a stress scenario. Finally, we show that the interaction of liquidity and solvency may lead to the amplification of equity losses due to funding costs which arise from liquidity needs. The approach described in this study provides in particular a clear methodology for quantifying the impact of economic shocks resulting from the ongoing COVID-19 crisis on the solvency and liquidity of financial institutions and may serve as a useful tool for calibrating policy responses.
\end{abstract}

JEL Classification Numbers: C63, G21, G32

Keywords: stress testing, solvency risk, liquidity risk, risk interaction, loss amplification

Author's E-Mail Address: Rama.Cont@maths.ox.ac.uk: Artur.Kotlicki@maths.ox.ac.uk: lvalderramaferrando@imf.org

\footnotetext{
*We thank Martin Čihák, Christian Gourieroux, Ivo Krznar, Eva Lütkebohmert, Matt Roberts-Sklar and seminar participants at the IMF Monetary and Capital Market Department, the Bank of England, the European Central Bank, the Swiss National Bank and ACPR/Banque de France for helpful comments and remarks. Rama Cont's research benefited from the Royal Society APEX Award for Excellence in Interdisciplinary Research (Royal Society Grant AX160182). The views expressed are those of the authors and do not necessarily represent the views of Norges Bank, the IMF Executive Board or IMF management.
} 


\section{Contents}

1 Introduction $\underline{3}$

2 A Framework for Joint Stress Testing of Solvency and Liquidity $\underline{6}$

2.1 Balance Sheet Representation . . . . . . . . . . . . . $\underline{6}$

2.2 Dynamics of Balance Sheet Components under Stress . . . . . . . . $\underline{9}$

2.3 Solvency-Liquidity Diagrams . . . . . . . . . . . . . . 17

2.4 Loss Amplification through Liquidity-Solvency Interaction . . . . . $\underline{18}$

3 Mapping of Balance Sheet Variables and Liquidity Templates $\underline{\underline{20}}$

3.1 Data Requirements . . . . . . . . . . . . . . . . . . . 20

3.2 Example of a G-SIB Balance Sheet . . . . . . . . . . . . $\underline{23}$

4 Liquidity at Risk $\underline{\underline{25}}$

4.1 A Conditional Measure of Liquidity Risk . . . . . . . . . . . . . 2

4.2 Examples ....................... . . 26

5 Concluding Remarks $\quad \underline{35}$

References $\quad \underline{36}$ 


\section{Introduction}

Stress testing of banks has become a pillar of bank supervision. Bank stress testing has mainly focused on solvency: a commonly used approach is to evaluate the exposure of bank portfolios to a macro-stress scenario and compare this exposure with the bank's capital in order to assess capital adequacy (Schuermann, 2014). This approach is in line with structural credit risk models which, following Merton (1974), have mainly emphasized solvency.

However it has become clear, especially in the wake of the 2008 global financial crisis, that a typical route to failure for financial institutions may be a lack of liquidity triggered by a loss of short term funding (Duffie, 2010; Gorton, 2012). As noted in a famous letter of the SEC Chairman to the Basel Committee relating the events which led to the failure of Bear Stearns ${ }^{1}$, which was triggered by a lack of liquidity resources, not capital. The failure of insurance giant AIG, which had a trillion dollar balance sheet, may be traced to a lack of liquidity resources to face margin calls resulting from its credit downgrade (McDonald and Paulson, 2015). This phenomenon is not new. As shown by Postel-Vinay (2016), Chicago state bank failures during the Great Depression were linked to lack of liquid assets to face deposit withdrawals. Blickle et al. (2019) show that the German banking crisis of 1931 was centered around the collapse of interbank and wholesale funding. More recently, the Spanish bank Banco Popular, which displayed a capital ratio 6.6 percent in the 2016 European stress test, failed because of a lack of liquidity in $2017^{2}$. These examples illustrate the importance of accurately modeling various channels of liquidity stress for stress testing of banks.

Regulators have taken initiatives for the monitoring and regulation of bank liquidity, such as the Liquidity Coverage Ratio (LCR) and the Net Stable Funding Ratio (NSFR), as well as liquidity stress testing to assess the adequacy of liquidity resources of banks. Liquidity stress tests focus on a bank's ability to withstand hypothetical liquidity shocks. The usefulness of such stress tests hinges on the choice of the stress scenarios used for the liquidity shocks. While the Basel III framework emphasizes the need for a unified stress testing approach, the assessment of solvency and liquidity risk has remained largely fragmented. Calibration of liquidity shocks is based on supervisor experience rather than a forward-looking assessment of market risk, notwithstanding the increased significance of margin requirements for derivatives under the new European (EMIR) and US (CFTC) rules (Cont, 2017). Current practice is to calibrate such scenarios based on stressed cash in-/outflows and depositor runoffs in recent crisis episodes, using a backward looking approach (European Central Bank, 2019). Although the implementation

\footnotetext{
${ }^{1}$ Letter to the Chairman of the Basel Committee on Banking Supervision on March 20, 2008 (https://www.sec.gov/news/press/2008/2008-48.htm).

${ }^{2}$ https://srb. europa.eu/en/content/banco-popular
} 
of the LCR ratio has imposed more stringent liquidity requirements and strengthened banks' liquidity risk practices, the calibration of these requirements is insensitive to the solvency position of the reporting bank and restricted to a prescribed scenario that may differ from the scenario that would deplete the bank's capital buffers.

Many theoretical and empirical studies have pointed to the importance of interactions between solvency and liquidity risk (Bernanke, 2013; Cecchetti and Kashyap, 2018; Farag et al., 2013; Morris and Shin, 2016; Pierret, 2015; Rochet and Vives, 2004; Schmitz et al., 2019; Basel Committee on Banking Supervision, 2015). Interactions between solvency and liquidity are present in models of bank runs and debt roll-over coordination failures (Allen and Gale, 1998; Diamond and Rajan, 2005; Rochet and Vives, 2004). In a two-period model with short- and long-term liabilities, Morris and Shin (2016) identify two components of credit risk: the "insolvency risk" associated with asset value realization being below debt value, and the "illiquidity risk" associated with a run by short-term creditors irrespective of the actual solvency state of the institution. Liang et al. (2013) present an extension of the approach by Morris and Shin (2016) to a multi-period dynamic bank run setting where a financial institution is financed through a mix of shortterm and long-term debt. A noteworthy implication of this model is that total default risk increases in both rollover frequency and the short-term debt ratio. Cont (2017) describes the role of margin requirements in the transformation of solvency risk into liquidity risk, thereby linking solvency and liquidity.

The importance of interplay between solvency and liquidity in the context of financial stability also has been evidenced in empirical studies (Cornett et al., 2011; Du et al., 2019; Pierret, 2015). Pierret (2015) shows that firms with increased solvency risk are more susceptible to liquidity problems and that the availability of short-term funding decreases with solvency risk. Du et al. (2019) present empirical evidence that indicators of credit quality affect counterparty choice, with the consequence that creditworthiness affects the volume rather than the price of shortterm funding. Schmitz et al. (2019) present evidence on the relationship between bank solvency and funding costs and show that neglecting the solvency-liquidity nexus leads to a significant underestimation of the impact of shocks on bank capital ratios.

Despite the evidence on the close link between liquidity and solvency, liquidity and capital requirements are calibrated more or less independently (Cecchetti and Kashyap, 2018) and liquidity stress tests are conducted separately from solvency stress tests (European Central Bank, 2019; Schuermann, 2014). The methodology used in the calibration of liquidity requirements and stress tests either fails to model the interaction of solvency and liquidity risk or includes only a limited channel for such interactions (Basel Committee on Banking Supervision, 2015). 
For example, in the Bank of Canada's MacroFinancial Risk Assessment Framework (MFRAF) solvency risk affects roll-over risk (Fique, 2017), while in the Austrian Central Bank's stress test, solvency risk limits the access of a financial institution to funding (Basel Committee on Banking Supervision, 2015) ${ }^{3}$.

Our goal is to tackle this issue in a systematic manner and build a joint stress testing framework for solvency and liquidity that addresses the interrelations between them. Building on ideas introduced in Cont (2017), we introduce a model in which shocks to asset values generate endogenous liquidity shocks arising from multiple solvency-liquidity interactions channels, thus affecting both the solvency and liquidity of a financial institution.

Contributions We propose a joint stress testing framework for solvency and liquidity: rather than modelling solvency and liquidity stress separately, we integrate the mechanisms through which they interact and analyze the implications of these interactions for the dynamics of a balance sheet under stress. These mechanisms, summarized in Figure 1, lead to

- endogenous liquidity shocks arising from solvency shocks, and

- the amplification of solvency shocks through funding costs arising from liquidity constraints.

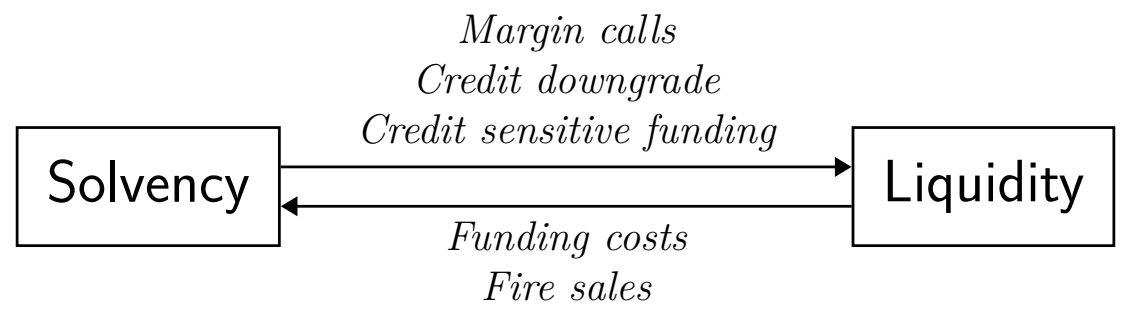

Figure 1: Mechanisms governing the solvency-liquidity nexus.

We start from a representation of a balance sheet, distinguishing various components in terms of their interaction with the firm's liquidity. We then express the various mechanisms through which these balance sheet components may be affected in a stress scenario, described as a shock to asset values ("solvency shock") 4 . Solvency shocks affect liquidity through margin requirements, via the firm's ability to raise short-term funding and through the cost of this funding, leading to endogenous liquidity shocks.

\footnotetext{
${ }^{3}$ See Table 18 in the online appendix to Baudino et al. (2018) for a summary of solvencyliquidity interactions in current bank stress-testing procedures.

${ }^{4}$ By contrast with MFRAF, we model contingent outflows from margin requirements, and allow the firm to raise funding in secured markets before resorting to fire sales.
} 
In addition to ensuring the coherence between liquidity and solvency stress scenarios, our approach has the benefit of avoiding the introduction of exogenous liquidity stress scenarios. In particular, we observe that identical shocks to risk factors may lead to different endogenous liquidity stress across banks, depending on their balance sheet composition. This feature is easily captured in our approach but would be difficult to implement in an approach where liquidity stress scenarios are specified exogenously.

Our approach also allows us to quantify the amplification of equity losses due to funding costs that arise from liquidity shortfalls. This illustrates how solvency risk may be underestimated by stress tests that do not account for the solvencyliquidity nexus.

The resilience of a balance sheet to the resulting combination of solvency shocks and endogenous liquidity shocks may be visualized through solvency-liquidity diagrams, introduced in Section 2.3. We define the concept of Liquidity at Risk, which quantifies the liquidity resources required for a financial institution facing a stress scenario. In contrast to the current methodology underlying the Liquidity Coverage Ratio (LCR), Liquidity at Risk is a forward-looking measure of liquidity stress conditional on a scenario defined in terms of co-movements in risk factors.

The stress testing methodology presented in this paper has been implemented as an online application available at http://liquidityatrisk.kotlicki.pl/.

Outline. Section 2 introduces the model and explains the various mechanisms through which solvency and liquidity interact. Section 3 discusses the extraction of model inputs from balance sheet and regulatory data. Section 4 introduces the concept of Liquidity at Risk and illustrates it with two examples: a synthetic balance sheet and the balance sheet of a global systemically important bank (G-SIB).

\section{A Framework for Joint Stress Testing of Sol- vency and Liquidity}

Figure 1 represents various mechanisms through which liquidity and solvency interact with each other. We introduce in this section a stress testing methodology that aims to capture these mechanisms.

\subsection{Balance Sheet Representation}

A coarse-grained representation of the balance sheet in terms of total assets and total liabilities turns out to be insufficiently detailed to model the mechanisms indicated in Figure 1. For instance, in order to quantify potential funding through 
repurchase agreements, one needs to distinguish unencumbered from encumbered assets and general collateral (GC) from other assets. In order to identify potential sources of margin calls, one needs to distinguish assets subject to margin requirements from other assets. In particular, our focus on distinguishing assets subject to variation margin is motivated by the balance sheets of global systemically important banks (G-SIBs) using publicly reported data as of October 2019. As shown in Figure 2, assets subject to variation margin typically form a large amount of total assets for G-SIBs ${ }^{5}$. In turn, these requirements may lead to large endogenous liquidity shocks during a stress and hence should be addressed adequately in liquidity stress tests.

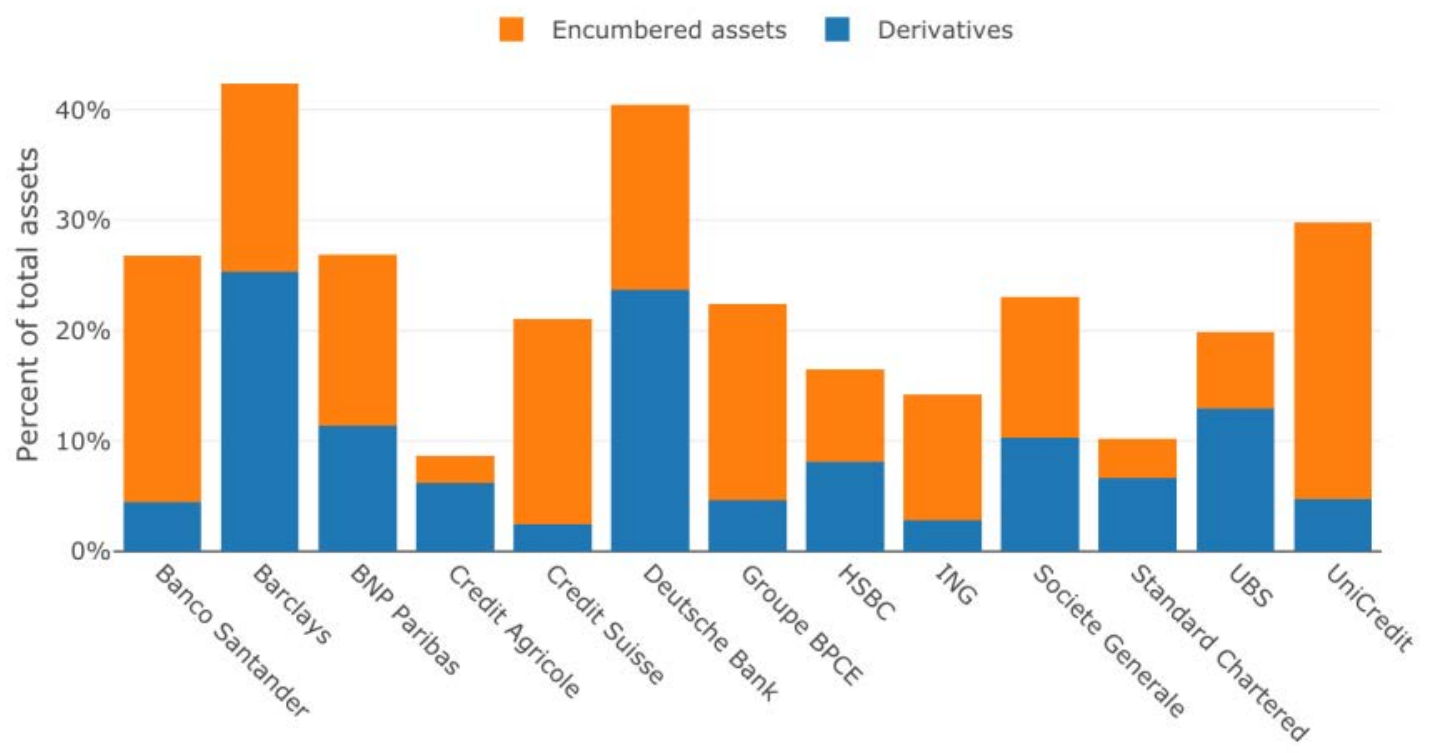

Figure 2: Assets subject to variation margin expressed as a fraction of a total value of assets for the 13 European G-SIBs (October 2019).

This warrants a more granular decomposition of the balance sheet into components based on their interactions with the solvency and liquidity, shown in Table 1.

On the asset side, we distinguish:

- Liquid assets, which include cash holdings; High Quality Liquid Assets (HQLA), easily convertible into cash; and balances with central banks.

- Marketable assets, defined as assets not in the above category but available for repo or sale. In particular such assets need to be unencumbered by exist-

\footnotetext{
${ }^{5}$ We note a weighed average (by the size of total assets) of 23 percent for the 13 most systemic banks as of October 2019.
} 


\begin{tabular}{|c|c|}
\hline Assets & Liabilities and equity \\
\hline \multirow{2}{*}{$\begin{array}{l}\text { Illiquid/encumbered assets: } \\
\text { - Subject to margin requirements, } I \\
\text { - Not subject to margin requirements, } J\end{array}$} & Maturing liabilities, $S$ \\
\hline & \multirow[b]{2}{*}{ Other liabilities, $L$} \\
\hline $\begin{array}{l}\text { Marketable unencumbered assets: } \\
\text { - Subject to margin requirements, } M\end{array}$ & \\
\hline $\begin{array}{l}\text { - Not subject to margin requirements, } N \\
\text { Liquid assets, } C\end{array}$ & Equity, $E$ \\
\hline
\end{tabular}

Table 1: Stylized balance sheet of a financial institution.

ing repurchase agreements. In the context of stress testing, it is conservative to assume that only (unencumbered) assets, mainly in the general collateral (GC) category (subject to a low haircut under stress) would be available for repo in a stress scenario, which is what we shall assume in the examples below. Among these marketable assets we further distinguish:

- Marketable assets subject to margin requirements; and

- Marketable assets not subject to margin requirements.

- Illiquid assets defined as assets that are not "marketable" as defined above. In particular, encumbered assets shall be considered under this category. Among these assets we further distinguish:

- Illiquid assets subject to margin requirements; and

- Illiquid assets not subject to margin requirements (typically loans).

On the liability side, we consider a (short) time horizon and we distinguish:

- Maturing liabilities, due within this short-term time horizon.

- Other liabilities maturing beyond this time horizon.

As explained below, to model the liquidity risk associated with margin calls and rollover of short-term (for example, overnight) funding, we consider a time horizon of the order of a few days.

The difference between total assets and total liabilities is represented by the firm's equity, denoted by $E$.

We discuss in Section 3 the mapping of balance sheet data and regulatory data to the format presented in Table 1. 


\subsection{Dynamics of Balance Sheet Components under Stress}

We now describe the dynamics of balance sheet components in a stress scenario over a short-time horizon. It is helpful to break up the sequence of balance sheet transformations occurring over this time horizon into two steps, as shown in Figure 3 .

This description of the evolution of balance sheet components over a short time horizon may be considered as a building block for a multi-period stress test.

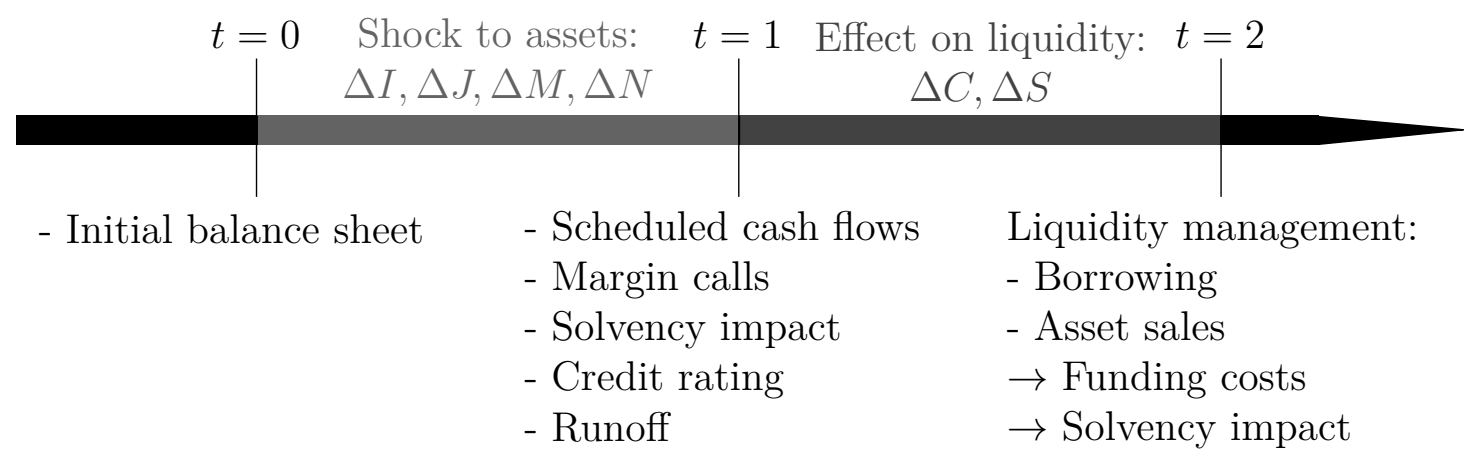

Figure 3: Evolution of balance sheet components.

Consider a leveraged financial institution with a balance sheet as in Table 1. We denote the initial value of balance sheet components by $I_{0}, J_{0}, M_{0}$, and $N_{0}$, the subscript 0 indicating their initial values at $t=0$. The initial value of maturing liabilities $S_{0}$ represents the amount of liabilities maturing at $t=2$, while $L_{0}$ represents the amount of liabilities maturing after $t=2 . C_{0}$ denotes the current level of cash reserves and balances with central banks.

We now consider the impact of an adverse market scenario on this balance sheet.

Stress scenarios Stress scenarios are typically defined in terms of shifts to risk factors such as real GDP, interest rates, credit spreads, equity prices, exchange rates, and other economic variables to which portfolio components are sensitive. Denoting these risk factors by $X=\left(X_{1}, \ldots, X_{d}\right)$, each stress scenario may be described in terms of shocks $\Delta X=\left(\Delta X_{1}, \ldots, \Delta X_{d}\right)$ to risk factors.

Direct impact on solvency The reaction of portfolio components to such a stress scenario is evaluated using models calibrated to the risk structure of the 
portfolio. The models used to derive stress impacts differ across default shocks and market shocks. While the effect of default shocks on credit exposures may take time to materialize, market shocks immediately affect the fair valuation of market exposures. To produce an integrated risk modelling framework, we assume that firms assess the impact of default shocks on equity using a forward-looking approach (rather than an incurred loss method), and thus the horizon over which shocks hit P\&L is the same across risk types. This view is consistent with the Basel III regulatory framework for internal-ratings based models, and the newly implemented accounting IFRS 9 provisions ${ }^{6}$.

For credit shocks, defaults are considered in lending positions (in general valued according to accrual accounting), traded credit positions ("issuer default"), positions measured at fair value and counterparty exposures like OTC derivatives and Securities Financing Transactions. Impairment losses reduce the carrying amount of credit risk positions affecting the value of equity. Impairment charges can be computed as the impact of stressed credit risk parameters - that is, probability of default (PD), loss given default (LGD) and exposure at default (EaD) - on the initial value of the position. Shifts to PDs, LGDs, and EaDs can be expressed in terms of sensitivities to underlying risk factors.

For market shocks, the impact of the shocks on bank portfolios at partial or full fair valuation measurement, can be calculated either by revaluation of the positions in the portfolio under the stress scenario (full valuation method) as computed in firm internal stress tests and regulatory bottom-up stress tests or, as done frequently in top-down regulatory stress tests, by using a linear approximation of the dependence of portfolio components with respect to risk factors, in terms of sensitivities to risk factors. Market shocks are exogenous shifts to risk factors prescribed in the stress test scenario which generate initial market losses. These shocks are different from the endogenous fire sales shocks derived endogenously from banks' liquidity risk mitigation actions.

Denoting $\partial_{k} A$ the sensitivity of balance sheet component $A$ to risk factor $X_{k}$, the change in the value of this balance sheet component in the risk scenario is then given by

$$
\Delta M=\sum_{k=1}^{d} \partial_{k} M . \Delta X_{k}=\partial M . \Delta X,
$$

where $\partial M$ denotes the vector of sensitives of balance sheet component $M$. Similarly we may compute the changes in balance sheet items $I, J, N$ as

$$
\Delta I=\partial I . \Delta X, \quad \Delta J=\partial J . \Delta X, \quad \Delta N=\partial N . \Delta X .
$$

\footnotetext{
${ }^{6}$ To compute regulatory capital, banks using internal-ratings based models for credit risk take a forward-looking approach to determine capital ratios. From an accounting perspective, IFRS 9 requires loan allowances based on 12 month expected losses if the credit risk has not increased significantly, and expected lifetime losses for exposures that have deteriorated significantly.
} 
These sensitivities may be computed using satellite models linking scenario shocks to credit risk parameters (default shocks), or calculating the impact of risk factors on fair-valued positions using the delta method (market shocks) ${ }^{7}$.

Impact on liquidity Liquidity risk arises from the uncertainty to meet payment obligations in a full and timely manner in a stressed environment. In the model, obligations coming due at $t=2$ include four components.

1. Unconditional liabilities: these are liabilities maturing at $t=2$. Their size corresponds to maturing liabilities and hence is denoted by $S_{0}$.

2. Scheduled cash outflows (SCO): these include contractual cash flow obligations (for example, interest payments on interest-bearing liabilities, coupons, operating costs), projected outflows from non-maturing liabilities (for example, sight, operational deposits) and estimated drawdowns of undrawn credit and liquidity lines ${ }^{8}$. Denoting these outflows by $S C O$, the stable component of short-term liabilities payable at $t=2$ can then be expressed as

$$
S_{1}=S_{0}+S C O
$$

3. Contingent liquidity risks: in a derivative transaction or securities financing transaction with no margin payments, although both sides may mark-tomarket their position daily, there is no exchange of cash flows: any losses or gains purely affect the solvency of the institution. In this case, capital buffers are an adequate tool to address any risk externalities. On the other hand, if an asset is subject to margin requirements, this creates a liquidity outflow in the form of a variation margin payment. As a result, such shock affects not only the solvency of the institution but also its liquidity by drawing on the held cash reserves with an immediate effect (typically within a few days), since all payments are made in cash or liquid assets. Firms post and receive collateral to support or reduce the counterparty credit risk (CCR) relative to derivative transactions or to securities financing transactions, including transactions cleared through a central counterparty (CCP). Here we focus on liquidity needs from changes in the value of collateral posted by the bank (for example, in repo transactions) rather than on collateral received (for example, in reverse repos) to allow an integrated assessment of the solvency and liquidity risk of the firm from valuation shocks to the bank assets. For

\footnotetext{
${ }^{7}$ See Section 3 for more details.

${ }^{8}$ Drawdowns of lines of credit are material for US banks Levine and Sarkar (2019) document that, together with expected margin calls, they account for around 20 percent of gross outflows in the LCR reported by G-SIBs.
} 
assets subject to variation margin, negative changes in asset values lead to margin calls that add to maturing liabilities, which we denote by

$$
\Delta S=(\Delta I)^{-}+(\Delta M)^{-},
$$

whereas positive changes generate margin calls to the counterparty, which lead to cash inflows expected at $t=2$, and which we denote by

$$
\Delta C=(\Delta I)^{+}+(\Delta M)^{+},
$$

where $(X)^{+}=\max (0, X)$ denotes the positive part of a quantity $X$ and $(X)^{-}=(-X)^{+}$. The interaction between solvency and liquidity risk through margin requirements and creditor runs may lead to a severe amplification of losses in a stressed environment.

4. Liquidity needs related to downgrade triggers: the direct impact of the shocks described above on the firm's equity is given by ${ }^{9}$

$$
E_{1}=E_{0}+\Delta I+\Delta J+\Delta M+\Delta N+S C I-S C O .
$$

If due to these losses the firm's equity falls below a threshold, then the firm may be subject to a credit downgrade. We assume such a downgrade occurs if the leverage ratio exceeds a level $\delta$, that is,

$$
\frac{I_{1}+J_{1}+M_{1}+N_{1}+C_{1}}{\left(E_{1}\right)^{+}}>\delta .
$$

Such a downgrade may trigger the loss of credit sensitive funding - including institutional and retail deposits that can be withdrawn on demand, and outflows associated with a downgrade in the bank's credit rating. We denote by $S_{D}$ the increase in maturing liabilities resulting from a downgrade ${ }^{10}$.

As a result, conditional on the stress scenario, maturing liabilities due at $t=2$ increase to

$$
S_{2}=S_{1}+\Delta S+S_{D} \mathbb{1}_{\text {downgrade }}
$$

On the other hand, the reserve of liquid assets is increased by the scheduled cash inflows from contractual claims (for example, interest payments) and maturing assets that are not reinvested (for example, inflows from performing exposures and secured lending). Denoting this amount by $S C I$, we have that

$$
C_{1}=C_{0}+S C I \text {. }
$$

\footnotetext{
${ }^{9}$ For simplicity, we assume that all scheduled cash flows have an equity impact, although most of the equity impact comes from interest that is expected to be received and paid during the horizon.

${ }^{10}$ The elasticity of customer deposits to a bank's credit downgrade is parameterized outside the framework.
} 
Mitigating actions At $t=1$, if liquid assets are not enough to cover conditional cash outflows (expected and unexpected), the bank can undertake mitigating actions (from its contingency funding plan and recovery plan) to cover the liquidity shortfall $\lambda$, which we define formally as

$$
\lambda=\left(S_{2}-\left\{C_{1}+\Delta C\right\}\right)^{+} .
$$

In the short term, a financial institution has access to several sources of funding, stated in the usual order of preference based on cost considerations. This pecking order is consistent with the Senior Financial Officer Survey conducted by the Federal Reserve (2019) for cash management operations of US banks. It has also been documented empirically by Blickle et al. (2019) for the systemic German liquidity crisis of 1931, and is in line with Kapadia et al. (2012) based on information from UK banks' contingency plans and the assessment of defensive actions actively taken during the global financial crisis:

1. Unsecuritized borrowing: we assume the financial institution to has access to short-term unsecuritized loans given at an exogenous market interest rate $r_{U}$. This access depends on the firm's creditworthiness: we assume that the firm's access to such funding ceases once it has been downgraded ${ }^{11}$. Furthermore, the distance to downgrade leads to an upper bound on the volume of unsecuritized lending available to the firm:

$$
v_{U}=\frac{\left(E_{1} \delta-\left\{I_{1}+J_{1}+M_{1}+N_{1}+C_{1}\right\}\right)^{+}}{1+r_{U} \delta} .
$$

In other words, highly leveraged institutions are considered less creditworthy and hence can access a smaller pool of liquidity than lesser leveraged firms. Subject to this constraint, the amount of money a financial institution will borrow through this channel can be expressed as

$$
B_{U}=\min \left(\lambda, v_{U}\right)
$$

2. Repurchase agreements (repo): banks can raise liquidity by entering a repurchase agreement (repo) with a market counterparty. This requires the provision of liquid marketable (unencumbered) collateral and thus the volume $v_{R}$ of liquidity the bank can raise through this channel is capped by

\footnotetext{
${ }^{11}$ The firm interacts with other financial institutions through the leverage constraint: the ability of a firm to tap interbank funding decreases when other banks choose not to roll over or grant new funding over solvency concerns. The propagation of funding stress through the interbank market is, however, outside the scope of the paper.
} 
the size $M_{1}+N_{1}$ of the firm's pool of unencumbered marketable assets, discounted by the corresponding haircut parameter $h \in[0,1)$, that is

$$
v_{R}=(1-h)\left(M_{1}+N_{1}\right) .
$$

Consequently, the amount of cash that the financial institution can raise through the repo market is then given by

$$
B_{R}=\min \left\{\lambda-B_{U},(1-h)\left(M_{1}+N_{1}\right)\right\},
$$

with an associated borrowing cost given by the (exogenous) repo rate $r_{R}$.

3. Central bank repo: one may also consider the possibility of raising short-term funding against collateral through a repo agreement with the central bank a possibility available to banks in many jurisdictions as a backup source of funding. An example of this is the Eurosystem collateral framework that has played a key role during the financial and sovereign debt crisis to help prevent large-scale liquidity-driven defaults in Europe (Bindseil et al., 2017). The central bank typically accepts a wider range of collateral than repo markets; this corresponds in our notation to a fraction $\widetilde{\theta}_{J} \in[0,1]$ of (unencumbered) illiquid assets. Compared to the repo market, a higher haircut $H>h$ is typically applied to the collateral pledged to secure such funding. The amount of funding that is raised through this channel is given by

$$
B_{C}=\min \left\{\lambda-B_{U}-B_{R},(1-H) \tilde{\theta}_{J} J_{1}\right\}
$$

and is capped by the value of the unencumbered collateral available net of the haircut applied, that is $(1-H) \widetilde{\theta}_{J} J_{1}$.

4. Liquidation of assets (fire sales): we assume that in the short-term a liquiditystressed financial institution can only sell a fraction $\theta_{J} \in[0,1]$ of its illiquid assets (that cannot be accepted as a collateral by the central bank) in a fire sale with a price discount $\psi \in[0,1)$. Note that only unencumbered illiquid assets can be monetized in a fire sale. In other words, the maximum amount of liquidity that can be raised during the short-term can be expressed as

$$
v_{F}=(1-\psi) \theta_{J} J_{1}
$$

The fraction $\theta_{J}$ depends for example on the available market liquidity and the length of the sales horizon. Consequently, we expect $\theta_{J}$ to be small in a stress test scenario. Similarly, we usually think of the associated fire sale discount as large (in excess of 50 percent) ${ }^{12}$.

\footnotetext{
${ }^{12}$ This is consistent with calibrated parameter values in the literature (Cont and Schaanning, 2016).
} 
These mitigating actions increase the liquidity buffer of the bank at $t=2$ to

$$
C_{2}=C_{1}+\Delta C+B_{U}+B_{R}+B_{C}+\omega v_{F},
$$

where $B_{U}$ represents the amount of new unsecuritized borrowing, the total amount of borrowing through repo is $B_{R}+B_{C}$, and $\omega \in[0,1]$ is an endogenous fraction of liquidated assets in a fire sale for a price discount of $\psi \in[0,1)$ such that

$$
\omega=\min \left\{\frac{\left(S_{2}-\left(C_{1}+\Delta C+B_{U}+B_{R}+B_{C}\right)\right)^{+}}{(1-\psi) \theta_{J} J_{1}}, 1\right\} .
$$

The amount of other liabilities rises by the amount of new liabilities from unsecured and secured funding and declines by the cash flow amount due to the run of credit risk sensitive funding, that is,

$$
L_{2}=L_{0}+\left(1+r_{U}\right) B_{U}+\left(1+r_{R}\right)\left(B_{R}+B_{C}\right)-S_{D} \mathbb{1}_{\text {downgrade }} .
$$

As a consequence of these mitigating actions, the value of equity reduces to

$$
E_{2}=E_{1}-r_{U} B_{U}-r_{R}\left(B_{R}+B_{C}\right)-\omega \psi \theta_{J} J_{1} .
$$

Insolvency and illiquidity A financial institution is deemed insolvent when the equity falls below a certain threshold, here taken without loss of generality to be zero. That is, a firm fails due to insolvency when $E_{2}<0$. On the other hand, it is said to be illiquid when maturing liabilities exceed the firm's capacity to raise liquidity, that is, $C_{2}<S_{2}$, where $C_{2}$ is the available liquidity, given by Equation (16) and $S_{2}$ are the maturing liabilities due at $t=2$, given by Equation (8). It is possible for a firm to be illiquid without being insolvent, as it is possible to be insolvent without being illiquid.

The dynamics of balance sheet components are summarized in Figure 4. 


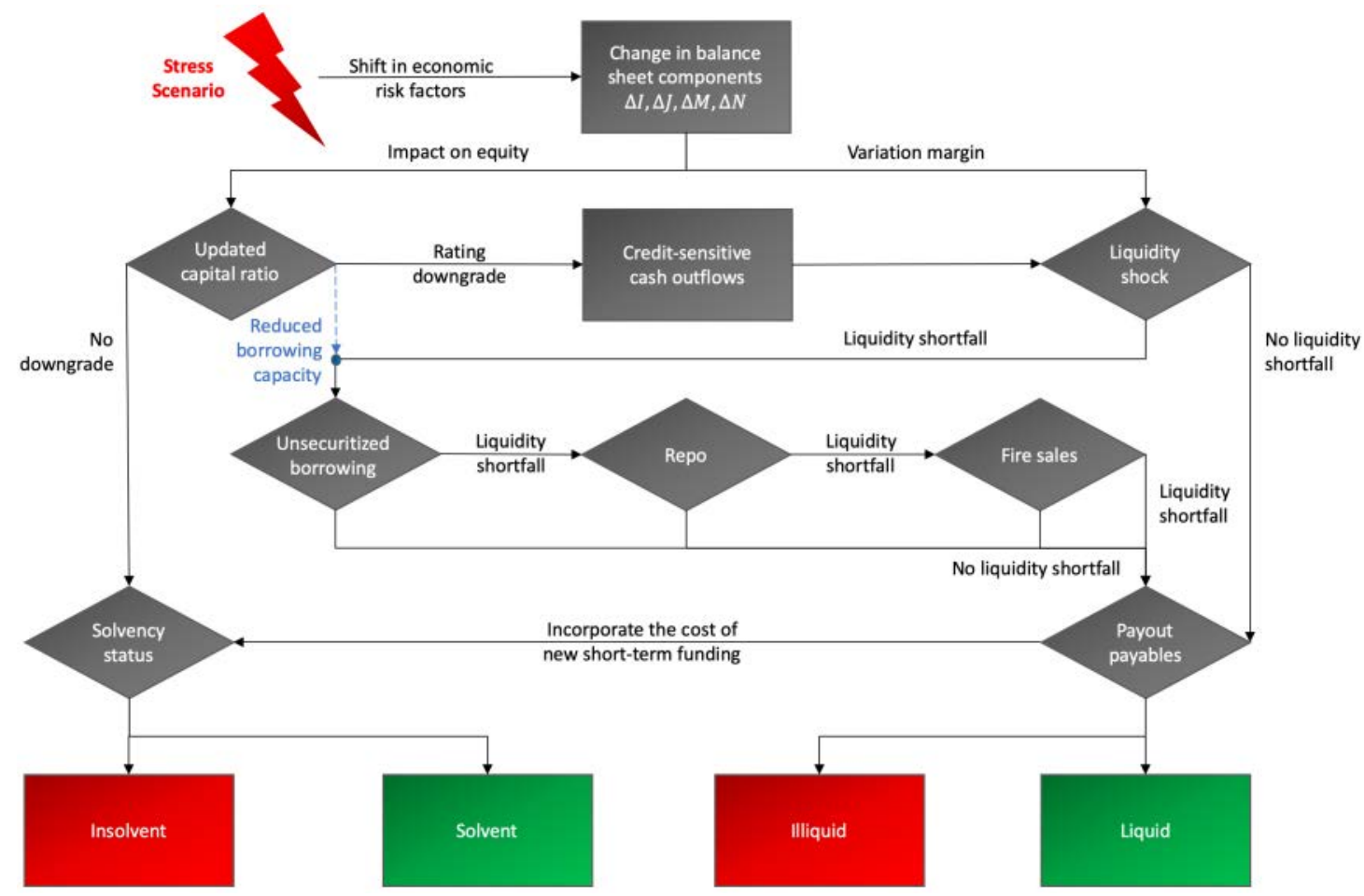

Figure 4: Joint stress test of solvency and liquidity. 


\subsection{Solvency-Liquidity Diagrams}

The balance sheet dynamics in a stress scenario may be visualized in the form of a solvency-liquidity diagram in which the financial institution's equity is represented on the horizontal axis and its liquidity resources on the vertical axis (see Figure 5).

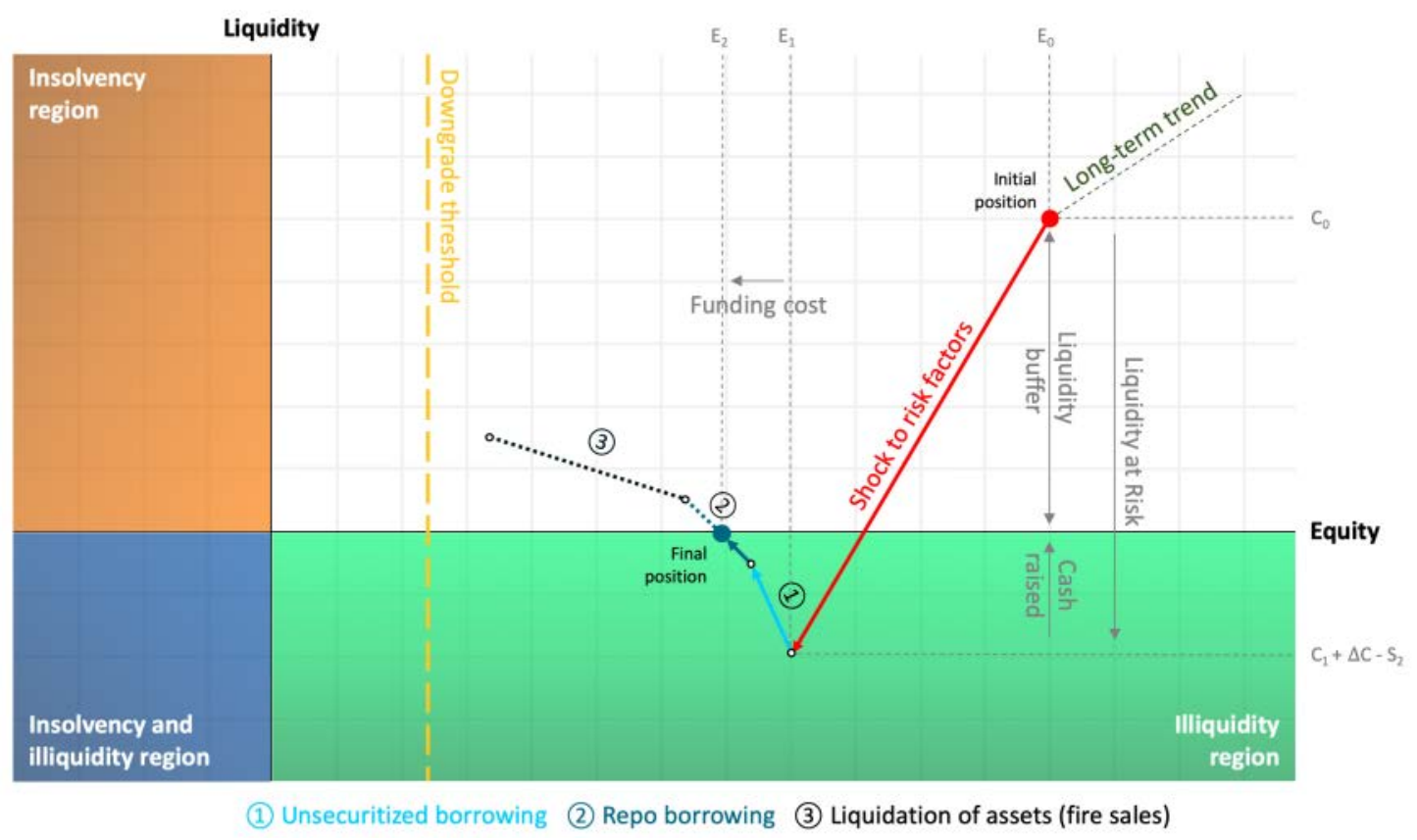

Figure 5: Solvency-liquidity diagram describing the behaviour of a balance sheet in a stress scenario.

A solvent and liquid institution corresponds to a point in the upper right quadrant (first quadrant). The vertical coordinate corresponds to its liquidity buffer while the horizontal coordinate correspond to the firm's equity.

A loss in asset values in a stress scenario moves this point to the left. Depending on the cash flows arising in the stress scenario, we may also have a vertical displacement upwards (if there is net incoming cash, for example due to the variation margin and interest received) or downwards (if there are net outflows, for example from margin and interest payments).

Failure occurs when the institution exits this first quadrant. If it crosses the horizontal axis (see Figure 6a), this corresponds to an illiquidity induced default, and if it crosses the vertical axis (see Figure 6b) this corresponds to failure due to insolvency. The distance to the axes represents the capital and liquidity buffers (see Figure 5).

An adverse stress scenario leads to a "south-west" shift on the diagram: the precise direction of the shift depends on balance sheet sensitivities, while the size 
of the shift corresponds to the severity of the shock. A pure solvency shock draws on the capital buffer without affecting the firm's liquidity reserves, and hence corresponds to a horizontal shift on the solvency-liquidity diagram. On the other hand, a pure liquidity shock caused by a run of creditors or a failure to rollover short-term debt due to a downgrade corresponds to a vertical shift on the diagram.

For a fixed adverse market scenario, the initial loss in equity due to the shock is independent of the balance sheet composition in terms of margin requirements. However, as the proportion of assets subject to variation margin increases, the reduction in the liquidity position of a financial institution (unencumbered assets) and its liquidity risk (sensitivity to market shocks) also increases. In that case, it becomes more likely that the firm becomes illiquid while still solvent as the shock severity increases.

\subsection{Loss Amplification through Liquidity-Solvency Inter- action}

The mechanisms described above may result in an amplification of the initial shock to the firm's equity.

In addition to the impact on equity due to the initial shock

$$
E_{1}-E_{0}=\Delta I+\Delta J+\Delta M+\Delta N+S C I-S C O
$$

funding costs lead to an additional loss in equity given by

$$
E_{2}-E_{1}=-r_{U} B_{U}-r_{R}\left(B_{R}+B_{C}\right)-\omega \psi \theta_{J} J_{1}
$$

This is represented by a horizontal shift in the solvency-liquidity diagram (Figure 5). This amplification effect may be quantified by the ratio of new funding costs to the initial shock to equity:

$$
\text { Loss amplification }=\frac{E_{2}-E_{1}}{E_{1}-E_{0}} \times 100 \% .
$$

Loss amplification increases in both the volume of new funding and the cost of raising new liquidity. Therefore, this effect becomes especially prominent for stressed institutions that are forced to liquidate a large amount of their assets in a fire sale.

In the model, the amplification effect occurs for shocks that lead to cash outflows larger than the current liquidity buffer held by the bank. However, if for example the firm aims to sustain a certain level of liquidity buffers, this effect can occur in practice for any adverse shocks.

We illustrate the significance of the loss amplification mechanism on numerical examples shown in Section 4.2. 


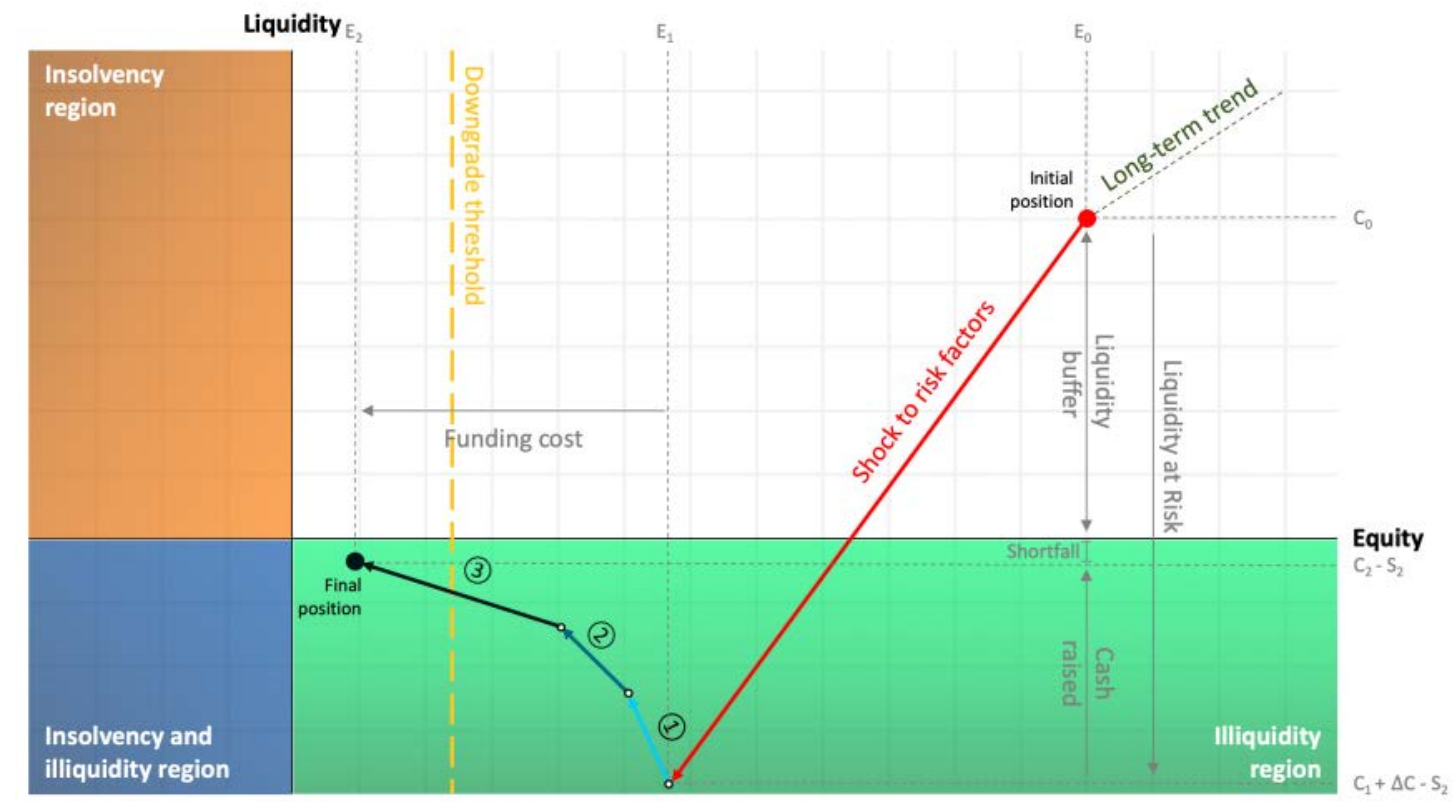

(1) Unsecuritized borrowing (2) Repo borrowing (3) Liquidation of assets (fire sales)

(a) Illiquidity induced failure.

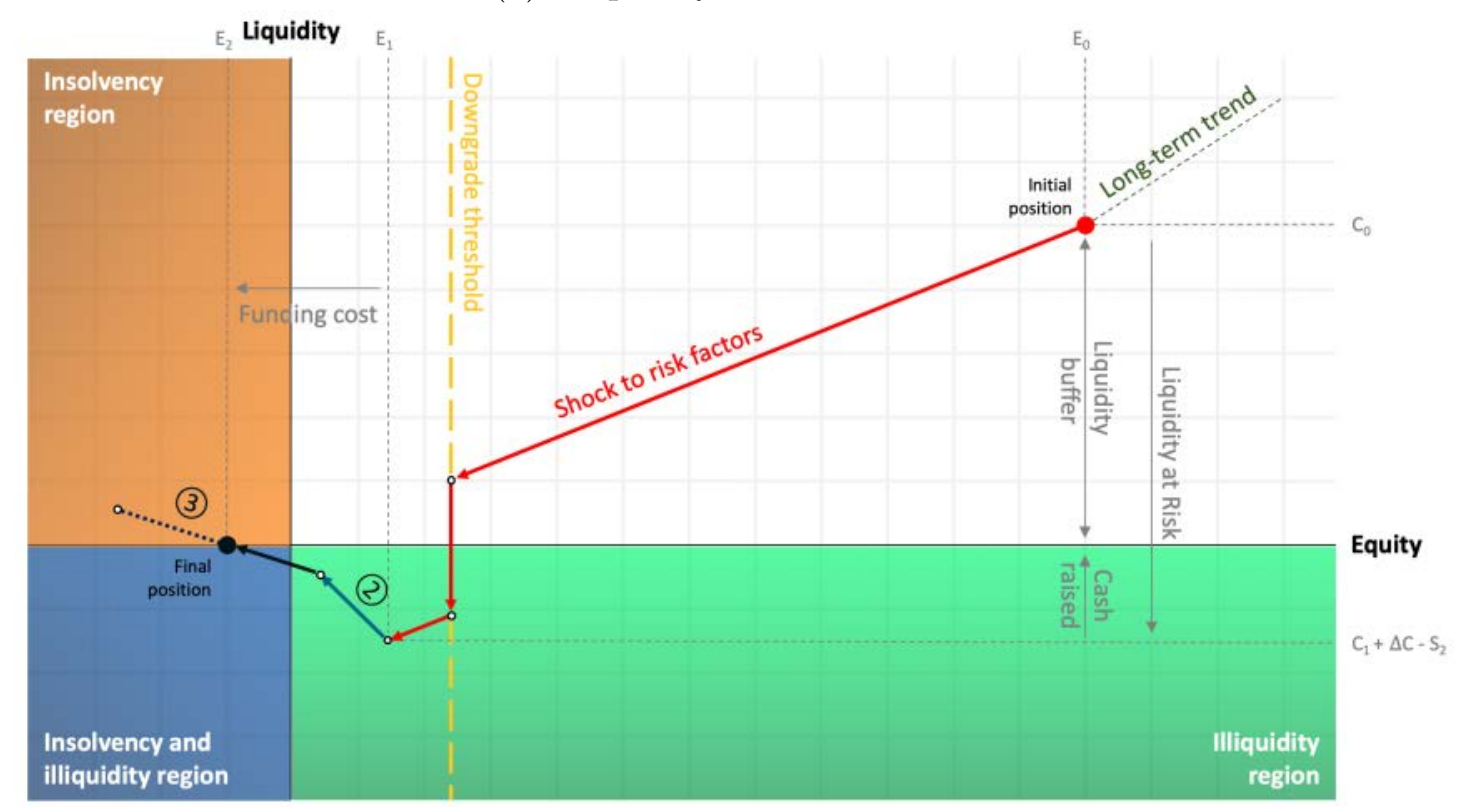

(2) Repo borrowing (3) Liquidation of assets (fire sales)

(b) Insolvency induced failure.

Figure 6: Examples of scenario analysis using solvency-liquidity diagrams. (a) Stress scenario leading to illiquidity. (b) Stress scenario leading to insolvency. 


\section{Mapping of Balance Sheet Variables and Liq- uidity Templates}

The purpose of this section is to show how balance sheet information - especially in the format of templates available to regulators - may be mapped to the format shown in Table 1 used as an input for our stress testing approach. In this section we describe how to use various data sources to generate the inputs required in our framework. We then provide a numerical illustration using publicly available data for a global systemically important bank (G-SIB).

\subsection{Data Requirements}

Our stress testing approach requires three types of inputs:

1. Balance sheet data, with sufficient granularity in order to extract the categories displayed in Table 1.

2. Risk parameters, including credit scores, internal risk reports, and market risk sensitivities to be used for estimating the profit and loss (P\&L) of various portfolio components in the stress scenario.

3. Liquidity data, to estimate the amount of available unencumbered assets, contractual maturity cash in-/outflows, and the potential liquidity generation capacity of securities over different time horizons.

These requirements are not very different from the inputs of current solvency stress tests but require the data to be formatted in a slightly different way, as discussed in Section 2. Central banks and regulators typically have access to data on portfolio positions, risk parameters, pricing models and methodologies to assess sensitivities to stress. For instance, in the European reporting framework, financial data are collected in Financial Reporting Framework (FINREP) templates, while risk data are submitted in Common Reporting Framework (COREP) templates. The reporting requirements, defined by the European Banking Authority (EBA) via the implementation of technical standards or guidelines, are complemented with short-term exercise ad-hoc data requests. These correspond to additional granular data on complex portfolios including sensitivities to moves in market risk factors. Our stress testing framework requires these data to be available at a sufficiently granular level to derive the above information for each component of the balance sheet.

Table 2 summarizes the mapping of asset categories observed in regulatory and accounting templates to balance sheet components required in the model. Assets are classified as "marketable" or "illiquid". Marketable refers to the availability 
of the assets for raising short-term funding in a stress scenario, either through a repurchase agreement or sale. Such assets therefore need to be unencumbered by other repurchase agreements. Because we are interested in behaviour of the balance sheet under stress, we restrict marketable assets to those that can generate liquidity through monetization at stressed haircuts over the relevant time horizon. Illiquid assets that can be subject to fire sales include loans, investments in associates, and physical assets. Assets that are not available to raise funding and cannot be pledged for repo transactions include complex hard-to-value assets (Level 3 in the fair value hierarchy), goodwill, and deferred tax assets.

\begin{tabular}{|l|l|l|}
\cline { 2 - 3 } \multicolumn{1}{c|}{} & $\begin{array}{l}\text { Not subject to } \\
\text { Variation Margin }\end{array}$ & $\begin{array}{l}\text { Subject to } \\
\text { Variation Margin }\end{array}$ \\
\hline $\begin{array}{l}\text { Illiquid } \\
\text { assets }\end{array}$ & $\begin{array}{l}\text { Loans } \\
\text { Non-financial investments } \\
\text { Physical assets }\end{array}$ & $\begin{array}{l}\text { Non-standard OTC derivatives } \\
\text { Encumbered assets }\end{array}$ \\
\hline $\begin{array}{l}\text { Marketable } \\
\text { assets }\end{array}$ & $\begin{array}{l}\text { Unencumbered GC: } \\
\text { - Assets held for trading } \\
\text { - Financial investments }\end{array}$ & $\begin{array}{l}\text { Exchange-traded derivatives } \\
\text { Standardized OTC derivatives }\end{array}$ \\
\hline $\begin{array}{l}\text { Liquidy } \\
\text { assets }\end{array}$ & $\begin{array}{l}\text { Cash (unencumbered) } \\
\text { Reverse repos }\end{array}$ & \\
\hline
\end{tabular}

Table 2: Mapping of common asset classes to the model input format.

Once the balance sheet data have been mapped to the format shown in Table 2, the stress test requires estimating the variations in each component in the stress scenario considered. The estimation of P\&L may be done either through full revaluation in a pricing model, which requires granular data on fixed-income and derivatives positions; or through a linear approximation, using sensitivities to risk factors. In the latter case, one would only require sensitivities to risk factors aggregated at the level of the balance sheet components shown in Table 1.

Projection of losses in stress scenarios typically involves two types of risk: credit risk and market risk.

For a credit risk assessment, the loss related to default events on lending positions, traded credit risk positions, and counterparty exposures like OTC derivatives needs to be projected. Impact on P\&L through newly created adjustments for loan loss provisions can be estimated using satellite models based on internal ratingsbased models or standardized approaches using stressed credit risk parameters. 
Under IFRS 9 accounting standards ${ }^{13}$, losses are generated from obligor grade migration using an expected loss, forward-looking approach. Similarly, the current expected credit loss (CECL) impairment model under US GAAP, will require banks to estimate expected credit losses over the contractual life of an instrument, before incurred losses materialize.

To assess market risk, we need to measure the impact of the shocks on the fair values of the underlying positions. Shocks include shifts to risk risk factors across asset classes including benchmark rates, credit spreads, foreign exchange, equities, and commodities. Accounting data serve to classify exposures at fair value (mark-to-market) relative to exposures at amortized cost. While shocks to financial assets held for trading and financial assets designated at fair value through P\&L impact directly, shocks to available-for-sale financial assets affect regulatory capital through Other Comprehensive Income (OCI). By contrast, shocks to held-to-maturity assets affect bank capital through an increase in provisions. The sensitivities with respect to the relevant (market) risk factors can be calculated using portfolio valuation models or requested from banks through usual regulatory submissions. These sensitivities report the impact of a risk factor move on the fair value of the position. Fire sale risk is reflected in the discount rate applied to the endogenous sale of illiquid assets. Raising liquidity by selling assets in a fire sale is the most costly management action. Therefore it is considered the last course of action.

Basel Liquidity Monitoring Templates (Pohl, 2017) provide a granular decomposition of cash outflows and inflows by time horizon, which can be exploited to estimate liquidity needs arising from an adverse scenario over a defined time horizon. To populate the cash flow equation, maturing liabilities according to current contractual conditions include securities issued, unsecured funding by retail and wholesale counterparties, liabilities from secured funding, and additional outflows from derivative transactions and other contingent obligations.

The stress test needs to project scheduled net cash outflows over the time horizon using the contractual maturity mismatch template and including estimated values on behavioral flows using banks' modelling assumptions or relying on Basel LCR-prescribed scenario assumptions. Contingent liabilities from a downgrade in the bank's credit rating can be estimated using bank's reported outflows in the liquidity templates, and applying stressed runoff rates on credit sensitive contractual outflows (for example, uninsured deposits, unsecured wholesale funding) based on historical experience.

\footnotetext{
${ }^{13}$ Under IFRS 9 implementation, credit risk is based on the categorisation of exposures in three stages: S1 (credit risk has not increased significantly since initial recognition, and provisions are based on a 12-month expected loss); S2 (credit risk has increased significantly, so the loss allowance should equal lifetime expected credit losses); and S3 (exposure is considered creditimpaired with lifetime allowance and non-recognition of interest accrual).
} 
Contingent liabilities from assets subject to margin requirements can be calculated by applying scenario shocks to risk factors on the value of collateral posted for counterparty credit risk exposure in derivative transactions and Securities Financing Transactions. These data are reported in the contractual mismatch and asset encumbrance submission of the Liquidity Monitoring Templates. While contingent outflows also can be triggered by financial instruments' price changes related to own securities issued, or unsecured funding instruments, these are typically not material.

\subsection{Example of a G-SIB Balance Sheet}

We now give an example of such a mapping based on publicly available data for a European G-SIB at end 2017. Public data sources include the bank's annual report, Pillar 3 disclosures, and the Fitch database. Balance sheet variables are mapped to the portfolio components of the balance sheet using portfolio data on credit risk and market risk positions.

Illiquid assets subject to margin requirements (asset class $I$ ) are mapped to encumbered assets pledged as collateral in derivative and securities financing transactions including trading portfolio assets ${ }^{14}$, loans, and financial assets designated at fair value. These positions amount to a value of $64021 \mathrm{M}$ EUR.

Illiquid assets not subject to margin requirements (asset class $J$ ) represent 514550 M EUR. These include three categories of assets:

1. Encumbered assets, not pledged as collateral, but restricted and not available to secure funding: this category includes mainly financial assets for unit-linked investment contracts, and some lending positions. They reach 23573 M EUR.

2. Assets that cannot be pledged as collateral: this category covers some loans, cash collateral on securities borrowed, reverse repurchase agreements, and other assets including cash collateral receivables, goodwill, and deferred tax assets. Assets in this category represent 167444 M EUR.

3. Other realisable assets. These assets include most lending positions (that is, loans in the banking book, due from banks, and financial assets designated at fair value), some trading portfolio assets, property investment, and investment in associates. The amount of realizable assets reaches $323532 \mathrm{M}$ EUR.

Marketable assets subject to margin requirements (asset class $M$ ) denote the fair value of derivative transactions including Level 1 and Level 2 assets of the fair value hierarchy. These contrast with Level 3 instruments that do not have

\footnotetext{
${ }^{14}$ This excludes financial assets for unit-linked investment contracts.
} 
quoted prices in active markets and rely on valuation models where significant inputs are not based on observable market data (for example, long-dated complex derivatives). The latter are considered non-marketable and cannot be monetized over a short time horizon. For the G-SIB considered in the example, derivative instruments include mainly interest rate and foreign exchange contracts, and to a lower extent equity contracts. Less significant are credit derivative and commodity contracts. The value of this category reaches $118227 \mathrm{M}$ EUR.

Finally, marketable assets not subject to margin requirements (asset class $N$ ) include unencumbered instruments available to secure funding. These marketable assets include financial assets at fair value for $45117 \mathrm{M}$ EUR, trading portfolio assets for $68369 \mathrm{M}$ EUR, financial assets available for sale for 8419 M EUR, and held-to-maturity instruments for $9166 \mathrm{M}$ EUR. Overall, category $N$ represents 131071 M EUR.

To complete the mapping of balance sheet assets, liquid assets (asset class $C$ ), including unencumbered cash and balances with central banks, amount to $87775 \mathrm{M}$ EUR. Equity reaches 51271 M EUR. Maturing liabilities represent outflows on retail deposits according to the bank modelling assumptions, and outflows on maturing unsecured debt. The remaining obligations are denoted as other liabilities. Scheduled cash outflows include contractual funding obligations for 13000 M EUR, outflows from secured wholesale funding for 79000 M EUR, and estimated drawdowns of committed credit and liquidity facilities for 9000 M EUR. Scheduled cash inflows include inflows from reverse repurchase agreements for 83000 M EUR, inflows from fully performing exposures for 33000 M EUR, and other cash inflows for 10000 M EUR.

The result of the mapping is shown in Table 3 .

\begin{tabular}{|l|l|}
\hline Assets & Liabilities and equity \\
\hline \hline $\begin{array}{l}\text { Illiquid assets: } \\
\text { - Subject to VM, } I_{0}=64021 \\
\text { - Not subject to VM, } J_{0}=514550\end{array}$ & Maturing liabilities, $S_{0}=37000$ \\
\cline { 2 - 2 } $\begin{array}{l}\text { Marketable unencumbered assets: } \\
\text { - Subject to VM, } M_{0}=118227 \\
\text { - Not subject to VM, } N_{0}=131071\end{array}$ & $\begin{array}{l}\text { Other liabilities, } L_{0}=827373 \\
\text { incl. deposits of } 409000)\end{array}$ \\
Liquid assets, $C_{0}=87775$ & Equity, $E_{0}=51271 \quad(5.6 \%)$ \\
\hline
\end{tabular}

Table 3: Simplified balance sheet of a European G-SIB for year 2017 (in millions of EUR). 


\section{Liquidity at Risk}

The framework introduced above enables us to move beyond a liquidity risk analysis purely based on exogenous expected cash flows: we define a concept of liquidity stress conditional on a stress scenario, which we baptize Liquidity at Risk.

\subsection{A Conditional Measure of Liquidity Risk}

Definition (Liquidity at Risk). Consider a stress scenario defined in terms of shocks to asset values. We call Liquidity at Risk associated with this stress scenario the net liquidity outflows resulting from this stress scenario:

$$
\begin{aligned}
& \text { Liquidity at Risk = Maturing Liabilities }+ \text { Net Scheduled Outflows } \\
& \quad+\text { Net Outflow of Variation Margin }+ \text { Credit-Contingent Cash Outflows }
\end{aligned}
$$

The liquidity shortfall in a stress scenario is thus given by the difference between the Liquidity at Risk associated with the stress scenario and the liquid assets available at the point where the scenario occurs.

Liquidity at Risk is easy to read off from the solvency-liquidity diagrams introduced in Section 2.3: it corresponds to the vertical shift (that is, the liquidity shock) induced by the stress scenario. In terms of the model variables defined in Section 2, we have

$$
\text { Liquidity at Risk }=S_{2}-\left(C_{1}-C_{0}+\Delta C\right) \text {. }
$$

We note that:

- Liquidity at Risk is a conditional concept: it quantifies the expected total draw on liquidity resources of the bank conditional on the stress scenario being considered. In particular, the evolution of liquid balances and maturing liabilities constitute a part of this measure.

- Liquidity at Risk measures a net outflow corresponding to the stress scenario considered. This can be compared to the liquidity resources potentially accessible by the bank in the stress scenario, including feasible mitigating actions, to assess the potential for default.

- In contrast to the Liquidity Coverage Ratio (LCR), which is estimated based on historical data on margin calls or average runoff rates, Liquidity at Risk is a portfolio-specific and forward-looking concept: it quantifies the liquidity stress for a specific portfolio conditional on a scenario defined in terms of co-movements in risk factors. 
The concept of Liquidity at Risk does not refer to a specific statistical model for generating risk scenarios. It may be applied to historical risk scenarios as well as hypothetical stress scenarios generated from a stochastic model for risk factors. In the case where one starts from such a statistical model for risk scenarios, one can define a corresponding notion of Liquidity at Risk given a certain confidence level (for example, 99 percent Liquidity at Risk). However, in this paper, we do not refer to a specific statistical assumptions about risk factors, and thus do not elaborate further in this direction.

\subsection{Examples}

We now illustrate the concept of Liquidity at Risk using two examples: a synthetic balance sheet and the balance sheet of a G-SIB.

\subsubsection{A Synthetic Bank Balance Sheet}

We consider a synthetic example of a bank balance sheet given in Table 4. Our example is representative of a typical balance sheet of a large commercial bank ${ }^{15}$, with a leverage ratio of 17.6. A large portion of the assets is allocated in a form of illiquid assets not subject to variation margin (mostly loans). Deposits are assumed to amount to 130000 M EUR, which corresponds to 60 percent of other liabilities.

\begin{tabular}{|l|l|}
\hline Assets & Liabilities and equity \\
\hline $\begin{array}{l}\text { Illiquid assets: } \\
\text { - Subject to VM, } I_{0}=16000 \\
\text { - Not subject to VM, } J_{0}=134000\end{array}$ & Maturing liabilities, $S_{0}=18000$ \\
\cline { 1 - 1 } $\begin{array}{l}\text { Marketable unencumbered assets: } \\
\text { - Subject to VM, } M_{0}=43000 \\
\text { - Not subject to VM, } N_{0}=16000\end{array}$ & Ether liabilities, $L_{0}=215000$ \\
Liquid assets, $C_{0}=38000$ & Equity, $E_{0}=14000$ \\
\hline
\end{tabular}

Table 4: A synthetic example of balance sheet for a representative large commercial bank (in millions of EUR).

The balance sheet is assumed to be sensitive to changes in interest rates and the equity market, as shown in Table 5. We consider two stress scenarios: a mild scenario of $\mathrm{a}+100$ bps increase in interest rates and a -200 bps decrease in the equity market, and a severe scenario of a +50 bps increase in interest rates and

\footnotetext{
${ }^{15}$ The synthetic balance sheet is motivated by the publicly available data on the 2016 JPMorgan Chase \& Co. balance sheet.
} 
a -500 bps decrease in the equity market. Loans are taken to be highly sensitive to changes in interest rates, while changes in the equity market are taken to have little to no effect on the illiquid assets. Consequently, in our example, an increase in interest rates is mostly a solvency-type shock, whereas changes in the equity market leads to large cash outflows due to the presence of margin requirements.

\begin{tabular}{|l|l|l|l|l|l|l|}
\cline { 2 - 7 } \multicolumn{1}{c|}{} & Risk factor & Shift & $\Delta I$ & $\Delta J$ & $\Delta M$ & $\Delta N$ \\
\hline \multirow{2}{*}{ Scenario I } & Interest rates & $+200 \mathrm{bps}$ & 400 & 4800 & 160 & 640 \\
\cline { 2 - 7 } & Equity market & $-750 \mathrm{bps}$ & 90 & 0 & 2150 & 400 \\
\hline \multirow{2}{*}{ Scenario II } & Interest rates & $+100 \mathrm{bps}$ & 200 & 2400 & 80 & 320 \\
\cline { 2 - 7 } & Equity market & $-1500 \mathrm{bps}$ & 180 & 0 & 4300 & 800 \\
\hline
\end{tabular}

Table 5: Sensitivities of the synthetic balance sheet shown in Table 4. Values represent a decrease in the value of balance sheet components (in millions) in response to a shift in the risk factor under a mild (I) and severe (II) stress scenario.

In both scenarios, we assume that only 5 percent of unencumbered illiquid assets can be readily liquidated in a fire sale at a price discount of 50 percent, and no illiquid assets are eligible for a repo with the central bank. Furthermore, we assume a repo haircut of 32 percent with associated repo rate of 5 percent, and unsecuritized borrowing rate of 1 percent is available to the bank as long as its leverage ratio does not exceed the threshold $\delta=20$. The money market benchmark rates are given in the scenario. The scheduled cash inflows in the example are taken to be 12000 M EUR, while outflows are set to 10000 M EUR. Finally, we assume a credit downgrade to trigger a severe depositor runoff of 58000 M EUR (45 percent of total deposits).

Scenario I Consider a scenario defined by a +200 bps move of interest rates and an equity market drop of $-750 \mathrm{bps}$. As a result of the initial shock, the bank's leverage ratio exceeds the creditworthiness threshold $\delta=20$ and hence becomes downgraded. The Liquidity at Risk in this scenario is 76800 M EUR: net cash outflows are comprised of 18000 M EUR in maturing liabilities, reduced by $2000 \mathrm{M}$ EUR in net scheduled inflows, $2800 \mathrm{M}$ EUR in variation margin and 58000 M EUR runoff due to downgrade. With an initial liquid assets buffer of 38000 M EUR, the bank faces a liquidity shortfall of 38800 M EUR, which needs to be covered by $37842 \mathrm{M}$ EUR in new repurchase agreements with an associated cost of $1892 \mathrm{M}$ EUR and $958 \mathrm{M}$ EUR in fire sales with an associated equity impact of 958 M EUR. As a result, the initial equity of 14000 M EUR (5.7 percent) is reduced by the adverse shock to $7360 \mathrm{M}$ EUR (3.0 percent), and drops further to 4510 M EUR (1.9 percent) due to incurred funding costs (Figure 7). Interactions between solvency and liquidity thus leads to a 43 percent loss amplification effect. 


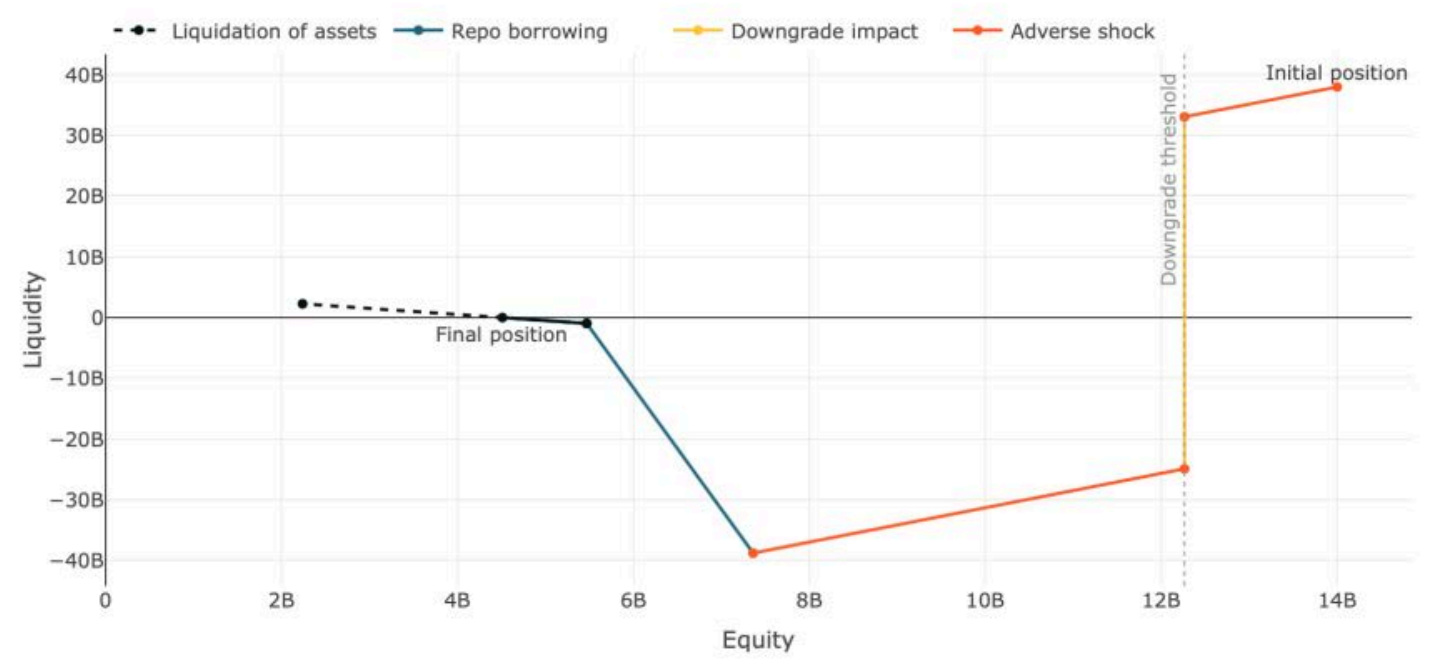

Figure 7: Solvency-liquidity diagram for the synthetic balance sheet shown in Table 4 in a stress scenario with +200 bps interest rates and -750 bps equity market moves.

Scenario II Consider now a severe market stress scenario defined by an interest rate increase of +100 bps and an equity market move of -1500 bps. Similarly to the previous scenario, the bank is in a breach of the creditworthiness threshold of $\delta=20$ that results in its downgrade. Consequently, the Liquidity at Risk for this scenario is $78760 \mathrm{M}$ EUR: the increase from the previous scenario is attributed to a larger variation margin outflow of $4760 \mathrm{M}$ EUR. This results in a liquidity shortfall of 40760 M EUR, which exceeds the maximum funding capacity of 39670 M EUR (36380 M EUR in repo and 3290 M EUR from assets liquidation), subsequently leading to a default. On the solvency side, the initial equity of $14000 \mathrm{M}$ EUR (5.7 percent) is reduced by the adverse shock to 7720 M EUR (3.2 percent), and drops further to 2611 M EUR (1.1 percent) due to funding costs: 1819 M EUR from repo and $3290 \mathrm{M}$ EUR from asset liquidation (see Figure 8). Interactions between solvency and liquidity thus leads to a 81 percent loss amplification effect.

Reverse stress testing So far we have discussed Liquidity at Risk in a single stress scenario. We can also use our approach to quantify solvency and liquidity impact across a range of adverse scenarios, parameterized by the severity of shocks to risk factors and identify "critical" shock amplitudes that potentially lead to insolvency or illiquidity. This "reverse stress testing" approach requires revaluation of balance sheet components under each scenario considered, but we may considerably simplify this calculation considerably using a sensitivity-based approach, that is, by assuming a linear impact of risk factors on the portfolio components. 


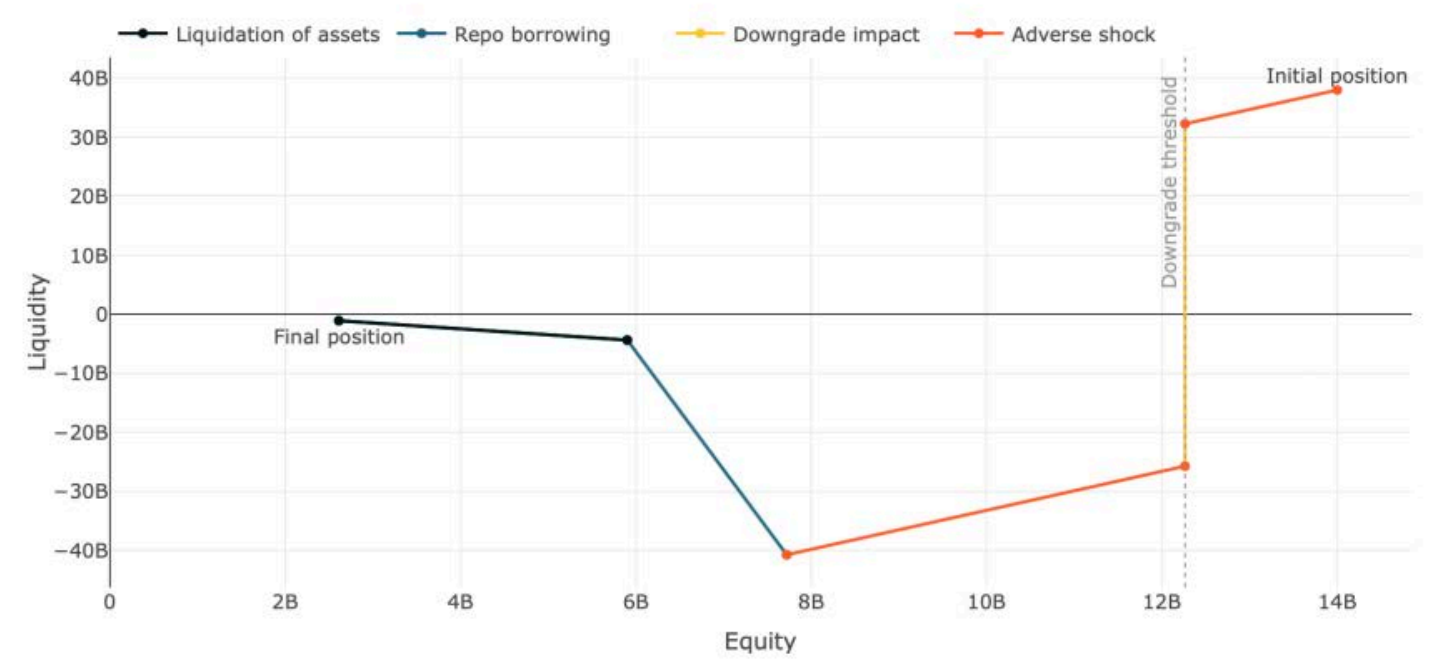

Figure 8: Solvency-liquidity diagram for the synthetic balance sheet shown in Table 4 in a stress scenario with +100 bps interest rates and -1500 bps equity market moves.

In the above example, this corresponds to using the sensitivities given in Table 5 to scale the impact of risk factor shocks on portfolio components across a range of amplitudes. Figure 9a summarizes the impact of a shock on interest rates and equity of up to 5 percent and 25 percent, respectively. Our example illustrates a crucial point: the interaction of solvency and liquidity risk matters when modeling default risk. Failure to incorporate it into a stress testing framework can significantly underestimate the total risk of a financial institution. An approach solely based on solvency risk would distinguish two regions in Figure 9a: a region of sufficient capital buffer (no failure) and a region of failure where loss of equity in a shock scenario exceeds the available buffer. Liquidity stress tests focus on sufficient liquidity buffers and the bank's ability to access sources of short-term funding in order to withstand adverse liquidity shocks. Consequently, independently conducted solvency and liquidity stress tests will fail to identify the regions where failure arises through the interaction of solvency and liquidity rather than through one channel alone, and thus will underestimate the risk of failure. These results are consistent with the observations in Schmitz et al. (2019), but push their conclusions further, showing that neglecting the liquidity-solvency nexus not only leads to the underestimation of solvency risk, but also of liquidity risk. The degree to which the credit risk is underestimated depends on the model parameters, balance sheet composition and sensitivities to risk factors.

Joint modelling of solvency and liquidity also leads to a more accurate representation of aggregate impact of a stress scenario on the firm's equity loss. Figure 9b 
illustrates the additional equity loss due to funding costs, as a percent of the direct equity loss resulting from the shock to risk factors. For the balance sheet shown in Table 4, the initial equity loss may be amplified by up to two times through solvency-liquidity interactions. Consequently, our methodology is not simply a juxtaposition of two stress tests: it provides a consistent joint stress testing framework for solvency and liquidity, taking their interactions into account. Appropriate modelling of the liquidity-solvency nexus is essential to capture the effect of these interactions to provide a more accurate stress testing framework.

The amplification effect is non-linear. When a financial institution defaults due to illiquidity, the cost of new funding is at its maximum: a firm will attempt to repo and liquidate all its eligible assets to cover for the liquidity shortfall, incurring a new, high new funding cost. Beyond this point, the amplification effect decreases for larger shock sizes because the funding cost no longer increases, as the bank no longer can increase the volume of its new funding, while the initial equity shock grows. In fact, for larger shocks the funding cost can decrease, since a shock can reduce the mark-to-market value of assets eligible for repo and sale, effectively reducing the total volume, and hence also the cost of new funding. On the other hand, for small shock sizes, the amplification remains small, as the firm can obtain new funding for a relatively low price. The amplification effect increases significantly beyond the fire sales threshold, which tends to be an extremely costly way of managing liquidity. Furthermore, the amplification effect increases around the downgrade threshold with an increase in the size of credit-sensitive funding. 


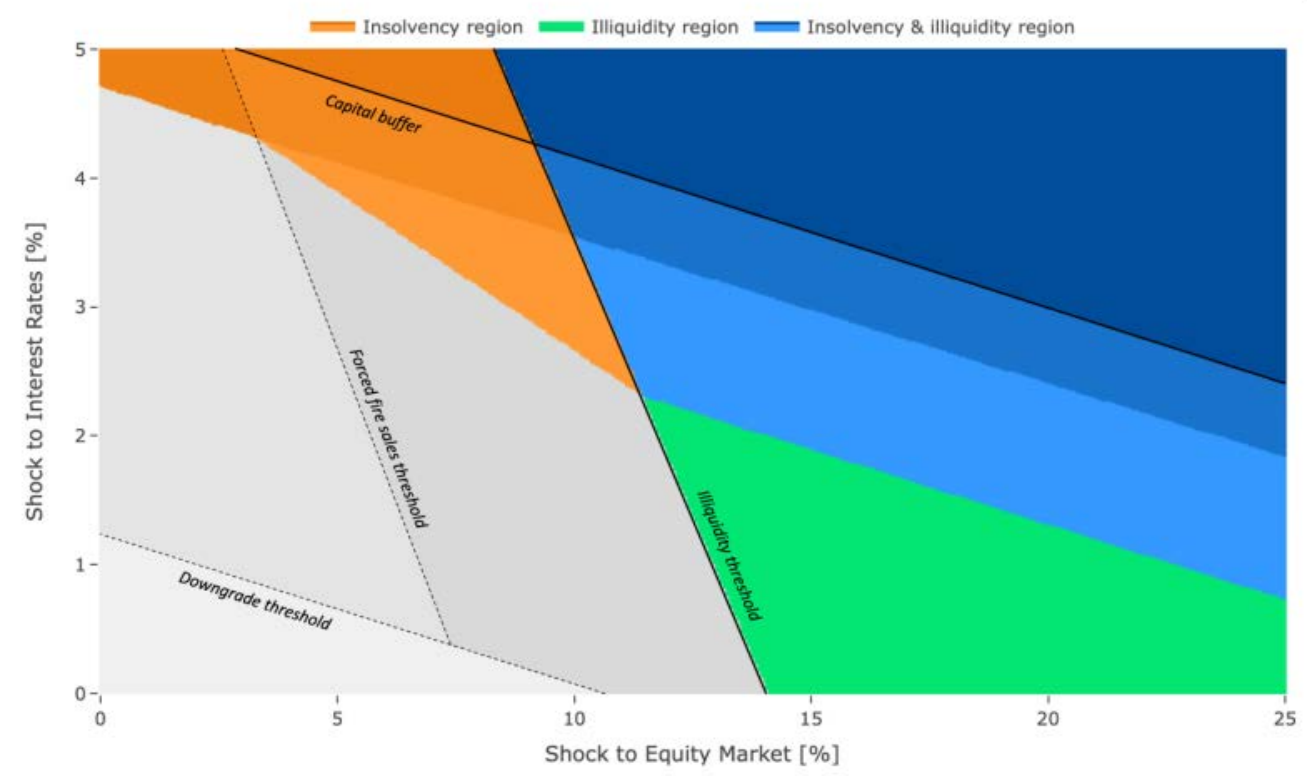

(a) Insolvency and illiquidity regions.

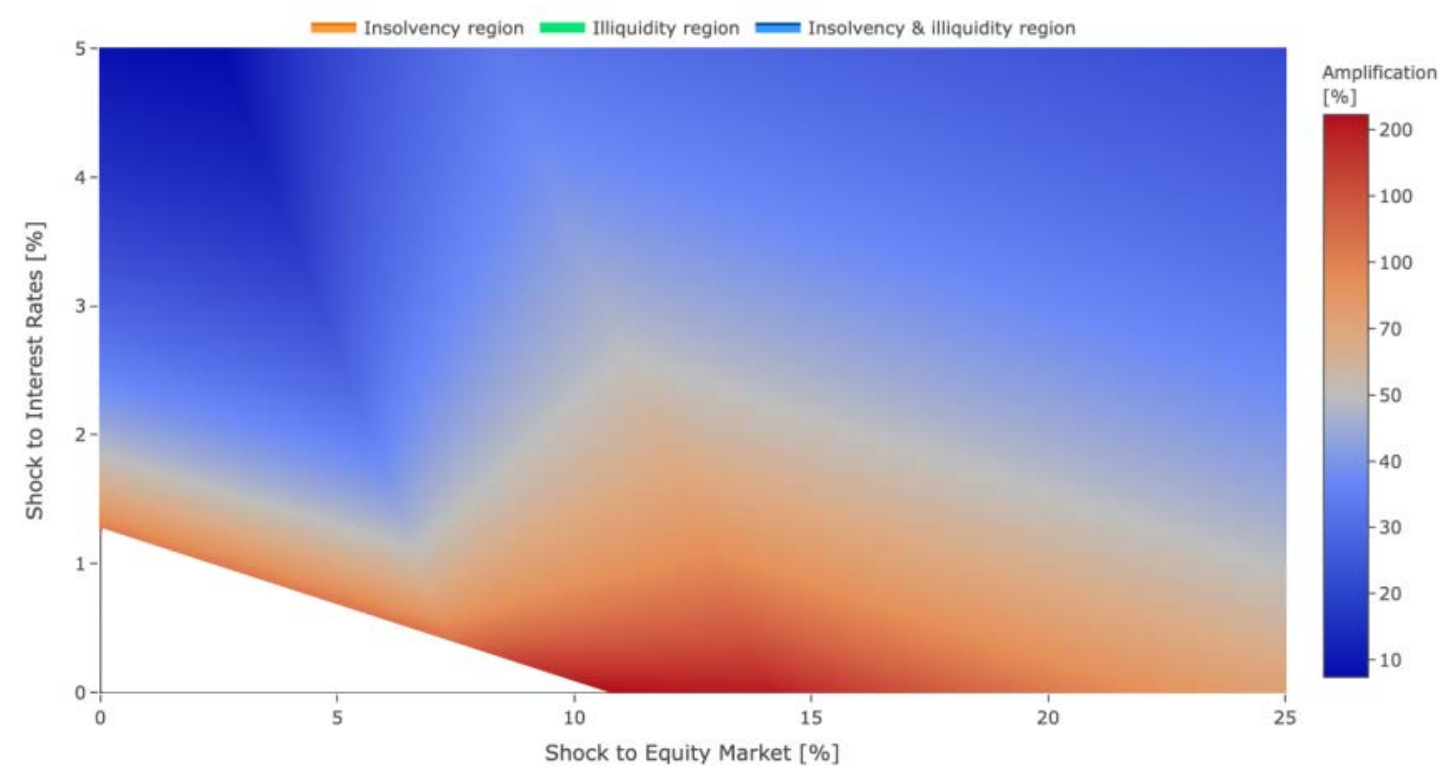

(b) Equity loss amplification due to funding costs (on a $\log _{10}$ scale).

Figure 9: Multiple stress test scenarios for a synthetic balance sheet, shown in Table 4, using linear extrapolation of sensitivities shown in Table 5. 


\subsubsection{A G-SIB Example}

Let us return to the G-SIB example from Section 3.2. Recall that Table 3 shows a simplified view of the consolidated balance sheet data for a G-SIB with a leverage ratio of 17.9, and whose sensitivities to two key risk factors are shown in Table 6 .

Similarly to the synthetic balance sheet example, we assume that in a stress scenario only 5 percent of unencumbered illiquid assets can be liquidated in the short-term with an associated 50 percent fire-sale discount, and no illiquid assets are eligible for a repo with the central bank. Funding through repo at a 5 percent rate requires a 32 percent haircut, while unsecuritized borrowing at 1 percent rate is available up to the downgrade threshold of $\delta=20$.

\begin{tabular}{|l|l|l|l|l|l|}
\hline Risk factor & Shift & $\Delta I$ & $\Delta J$ & $\Delta M$ & $\Delta N$ \\
\hline Interest rates & $+200 \mathrm{bps}$ & 1250 & 17000 & 2100 & 3600 \\
\hline Equity market & $-750 \mathrm{bps}$ & 3900 & 0 & 4200 & 4600 \\
\hline
\end{tabular}

Table 6: Balance sheet sensitivities for the balance sheet shown in Table 3. Values represent a decrease in the value of balance sheet components (in millions EUR) in response to a shift in the risk factor.

We subject this balance sheet to a stress scenario (Scenario I in Section 4.2.1) defined by an interest rates move of $+200 \mathrm{bps}$, and an equity price move of -750 bps. We estimate stressed run-off rates contingent on a downgrade scenario calibrated on real crisis cases in line with the 2019 ECB Sensitivity Analysis of Liquidity Risk under the extreme scenario. We apply differentiated run-off rates across different types of deposits to the liability structure of the G-SIB. This results in an aggregate 55 percent runoff rate of the aggregate customer deposit base (224950 M EUR). The impact of this stress scenario can be represented through a solvency-liquidity diagram, shown in Figure 10.

The effect of the scenario on the bank's net worth raises financial leverage, leading to an increase in the probability of default, and triggering a credit rating downgrade. Liquidity at Risk conditional on this scenario equals 248400 M EUR: 11450 M EUR payable in variation margin, 37000 M EUR due to maturing liabilities, 101000 M EUR due to SCO reduced by 126000 M EUR from SCI, and 224950 M EUR due to the runoff on deposits. This exceeds the bank's liquidity buffer of $87775 \mathrm{M}$ EUR, and results in a liquidity shortfall of $160625 \mathrm{M} \mathrm{EUR,}$ which can be fully covered by borrowing in secured markets (159662 M EUR for a cost of $7983 \mathrm{M} \mathrm{EUR)} \mathrm{and} \mathrm{through} \mathrm{liquidation} \mathrm{of} \mathrm{assets} \mathrm{(962} \mathrm{M} \mathrm{EUR} \mathrm{with} \mathrm{an}$ equity impact of $962 \mathrm{M} \mathrm{EUR).} \mathrm{As} \mathrm{a} \mathrm{result,} \mathrm{the} \mathrm{initial} \mathrm{equity} \mathrm{of} 51271$ M EUR (5.6

percent) is reduced by the adverse scenario to $39621 \mathrm{M}$ EUR (4.4 percent), and drops further to 30675 M EUR (3.4 percent) due to incurred funding costs, leading to a 77 percent loss amplification effect. 


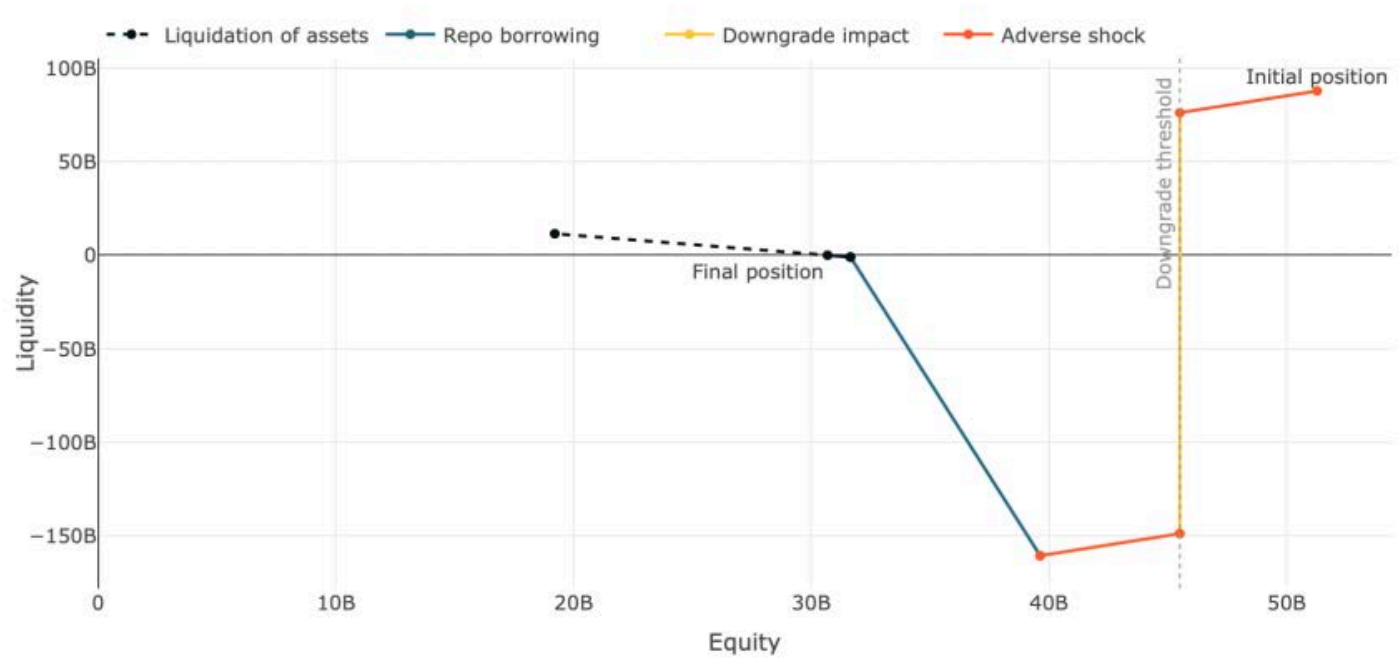

Figure 10: Solvency-liquidity diagram for the G-SIB balance sheet shown in Table 3 in a stress scenario with +200 bps interest rates and -750 bps equity market moves.

Comparing this example with the synthetic portfolio in Section 4.2.1, we observe that the same stress scenario applied to risk factors leads to different liquidity shocks to the balance sheet. The resulting liquidity shocks are endogenous and strongly dependent on balance sheet composition, funding structure, and bank resilience. This is quite different from the current practice of applying exogenous liquidity stress scenarios in liquidity stress tests (European Central Bank, 2019).

Reverse stress testing Using the same linear impact assumptions as in the previous example, we can extrapolate this analysis to other scenarios obtained by scaling the shocks to risk factors. The corresponding outcomes are represented in Figure 11a. Under the severe depositor runoff assumption of 55 percent we see that liquidity risk becomes a major component of the default risk for large shocks.

A non-linear amplification effect emerges due to interaction between solvency and liquidity, as discussed previously. The loss amplification becomes most significant for large equity market moves of about 1800 bps with no moves in interest rates - in this case, the initial loss is amplified by more than 350 percent due to the high cost of new funding. On the other hand, for small shocks sizes that do not lead to a downgrade, the bank holds sufficient amount of liquidity buffer to cover its liquidity at risk in full, and thus we do not see any loss amplification effect. It should be noted that the loss amplification effect crucially depends on the funding sources that a bank is able to tap under stress. 


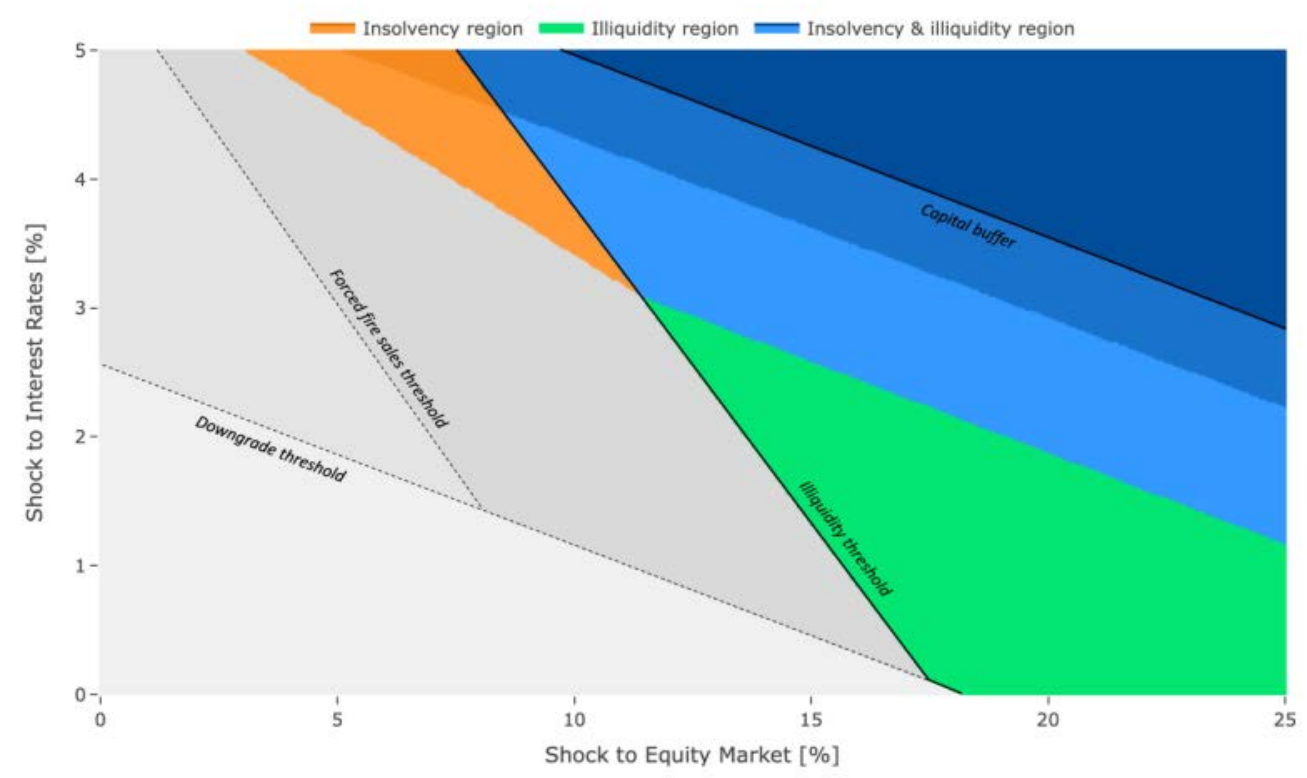

(a) Insolvency and illiquidity regions.

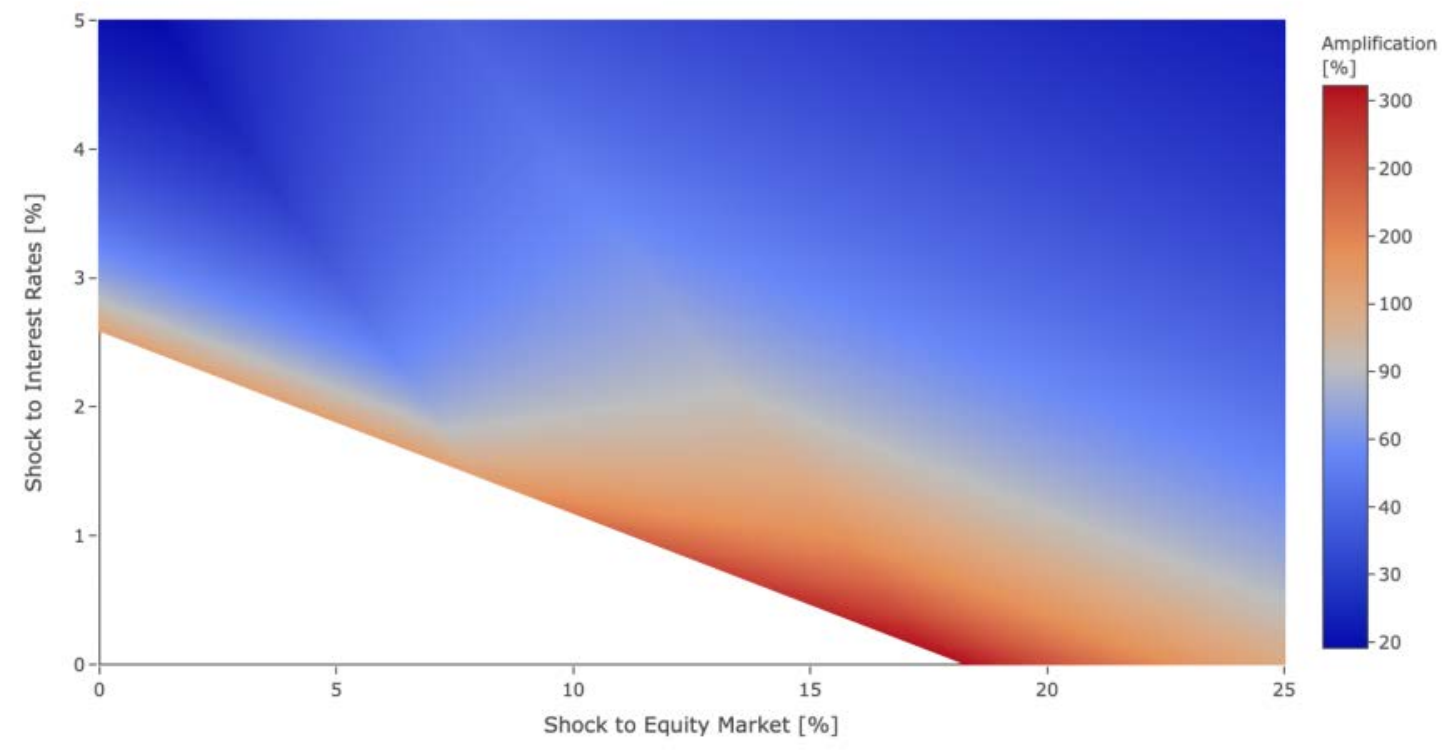

(b) Equity loss amplification due to funding costs (on a $\log _{10}$ scale).

Figure 11: Multiple stress test scenarios for a G-SIB balance sheet, shown in Table 3, using linear extrapolation of sensitivities shown in Table 6 . 


\section{Concluding Remarks}

Financial crises have repeatedly confirmed that the lack of liquidity is an inherent risk throughout the banking sector (Pohl, 2017). Liquidity and solvency are two interrelated dimensions of credit risk that cannot be modelled, or stressed, separately. Nonetheless, the interaction between liquidity and solvency tends to be omitted in stress testing practices. In response to calls from regulators to develop integrated liquidity and solvency stress tests (Basel Committee on Banking Supervision, 2015), we have developed a coherent framework for joint stress testing of solvency and liquidity risk.

In our framework, solvency shocks affect liquidity through margin requirements, via firm's ability to raise short-term funding, and through credit risk sensitive outflows. Consequently, this leads to endogenous liquidity shocks. In turn, solvency stress is exacerbated through the cost of new funding resulting from a liquidity shortfall, and fire sales. We distinguish between two types of failure: financial institutions can become illiquid without being insolvent, insolvent while remaining liquid, or - in the case of extreme shocks - both illiquid and insolvent. The model illustrates the danger of underestimating credit risk by models that do not account for the solvency-liquidity nexus. As shown by our examples, balance sheet composition has a significant effect on the solvency-liquidity nexus. In particular, our insights show that structural solvency risk models are insufficient to capture this dependency and we advocate the use of a more granular balance sheet view by the regulators when conducting a stress test.

Our proposed framework provides a more realistic stress test framework which establishes coherence between design of solvency and liquidity stress tests. It also includes mitigating actions that can be extracted from the bank's contingency funding plan and recovery plan. By defining the concept of Liquidity at Risk, we provide a tool to quantify the total draw on liquidity resources of the bank conditional on the stress scenario defined directly in terms of an adverse shock to risk factors. Sudden liquidity stress can result in the inability to obtain sufficient funding in due time and can lead to insolvency.

The tool is calibrated using available regulatory templates on financial data, risk data, and liquidity monitoring templates. The model is amenable to reverse stress testing and naturally permits a range of sensitivity tests around crucial inputs including changes to the classification of fair valued instruments, the liquidity generation capacity of unencumbered securities, the evolution of market haircuts and funding costs, and fluctuations in creditors' risk appetite framework.

The model yields useful policy implications for central banks and supervisory authorities. It helps supervisors to identify whether managerial options to fend off liquidity risk are helpful in avoiding insolvency or illiquidity in plausible stress scenarios. It also enables to identify sources of systemic spillovers, that is, shocks 
to risk factors that can become a conduit of systemic risk propagation and can threaten financial stability. Crucially, it helps authorities to make better decisions regarding the provision of central bank emergency liquidity assistance (ELA) to "illiquid but solvent" financial institutions. Ultimately, it serves to quantify the amount of resolution funding, which remain perhaps the key likely impediment in banking resolution.

\section{References}

Franklin Allen and Douglas Gale. Optimal financial crises. The Journal of Finance, 53(4):1245-1284, 1998.

Basel Committee on Banking Supervision. Making supervisory stress tests more macroprudential: Considering liquidity and solvency interactions and systemic risk. Working Paper 29, Bank for International Settlements, November 2015.

Patrizia Baudino, Roland Goetschmann, Jérôme Henry, Ken Taniguchi, and Weisha Zhu. Stress-testing banks - a comparative analysis. Financial Stability Institute Insights on policy implementation No 12, Bank for International Settlements, November 2018.

Ben Bernanke. The Federal Reserve and the financial crisis. Princeton University Press, 2013.

Ulrich Bindseil, Marco Corsi, Benjamin Sahel, and Ad Visser. The eurosystem collateral framework explained. ECB Occasional Paper, 2017.

Kristian Blickle, Markus K Brunnermeier, and Stephan Luck. Micro-Evidence From a System-Wide Financial Meltdown: The German Crisis of 1931. Working paper, 2019.

Stephen Cecchetti and Anil Kashyap. What Binds? Interactions between Bank Capital and Liquidity Regulations. The Changing Fortunes of Central Banking, pages 192-202, 2018.

Rama Cont. Central clearing and risk transformation. Financial Stability Review, pages 127-140, April 2017.

Rama Cont and Eric Schaanning. Fire sales, indirect contagion and systemic stress-testing. Working paper, Norges Bank, 2016.

Marcia Millon Cornett, Jamie John McNutt, Philip E Strahan, and Hassan Tehranian. Liquidity risk management and credit supply in the financial crisis. Journal of Financial Economics, 101(2):297-312, 2011. 
Douglas W. Diamond and Raghuram G. Rajan. Liquidity Shortages and Banking Crises. The Journal of Finance, 60(2):615-647, 2005.

Wenxin Du, Salil Gadgil, Michael B Gordy, and Clara Vega. Counterparty risk and counterparty choice in the credit default swap market. Working paper, Federal Reserve Board, 2019.

Darrell Duffie. How Big Banks Fail and What to Do about It. Princeton University Press, 2010.

European Central Bank. ECB Sensitivity analysis of Liquidity Risk - Stress Test 2019. Methodological note, Banking Supervision, February 2019.

Marc Farag, Damian Harland, and Dan Nixon. Bank capital and liquidity. Bank of England Quarterly Bulletin, September 2013.

Federal Reserve. August 2019 Senior Financial Officer Survey. Board of Governors of the Federal Reserve System, August 2019.

Jose Fique. The MacroFinancial Risk Assessment Framework (MFRAF), Version 2.0. Technical Report No. 111, Bank of Canada, 2017.

Gary Gorton. Misunderstanding financial crises. Oxford University Press, 2012.

Sujit Kapadia, Matthias Drehmann, John Elliott, and Gabriel Sterne. Liquidity risk, cash flow constraints, and systemic feedbacks. In Quantifying Systemic Risk, pages 29-61. University of Chicago Press, 2012.

J. Levine and A. Sarkar. How Do Large Banks Manage Their Cash? Liberty Street Economics, Federal Reserve Bank of New York, 2019.

Gechun Liang, Eva Lütkebohmert, and Yajun Xiao. A multiperiod bank run model for liquidity risk. Review of Finance, pages 1-40, 2013.

Robert McDonald and Anna Paulson. AIG in Hindsight. Journal of Economic Perspectives, 29(2):81-106, 2015.

Robert C Merton. On the Pricing of Corporate Debt: The Risk Structure of Interest Rates. Journal of Finance, 29(2):449-70, May 1974.

Stephen Morris and Hyun Song Shin. Illiquidity component of credit risk. International Economic Review, 57(4):1135-1148, 2016.

Diane Pierret. Systemic Risk and the Solvency-Liquidity Nexus of Banks. International Journal of Central Banking, 11(3):193-227, 2015. 
Michael Pohl. Basel III liquidity risk monitoring tools. Occasional paper no. 14, Bank for International Settlements, October 2017.

Natacha Postel-Vinay. What Caused Chicago Bank Failures in the Great Depression? A Look at the 1920s. The Journal of Economic History, 76(2):478-519, 2016.

Jean-Charles Rochet and Xavier Vives. Coordination failures and the lender of last resort: was Bagehot right after all? Journal of the European Economic Association, 2(6):1116-1147, 2004.

Stefan W. Schmitz, Michael Sigmund, and Laura Valderrama. The interaction between bank solvency and funding costs: A crucial effect in stress tests. Economic Notes, (in press), 2019.

Til Schuermann. Stress testing banks. International Journal of Forecasting, 30(3): $717-728,2014$. 